UNIVERSIDADE DE SÃO PAULO

INSTITUTO DE PSICOLOGIA

SHEILA DE MARCHI

\title{
A arte como intermediador terapêutico para 0 desenvolvimento humano
}


SHEILA DE MARCHI

\section{A arte como intermediador terapêutico para 0 desenvolvimento humano

\author{
(Versão corrigida)
}

Dissertação apresentada ao Instituto de Psicologia da Universidade de São Paulo para obtenção de título de Mestre em Psicologia Clínica

Projeto apoiado pela Fundação de Amparo à Pesquisa do Estado de São Paulo. Processo n 2009/07003-0

Área de concentração: Psicologia Clínica

Orientador: Prof. Dr. Andrés Eduardo Aguirre Antúnez 
AUTORIZO REPRODUÇÃO E DIVULGAÇÃO TOTAL OU PARCIAL DESTE TRABALHO, POR QUALQUER MEIO CONVENCIONAL OU ELETRÔNICO, PARA FINS DE ESTUDO E PESQUISA, DESDE QUE CITADA A FONTE.

Catalogação na publicação

Biblioteca Dante Moreira Leite

Instituto de Psicologia da Universidade de São Paulo

De Marchi, Sheila.

A arte como intermediador terapêutico para o desenvolvimento humano / Sheila De Marchi; orientador Andrés Eduardo Aguirre Antúnez. -- São Paulo, 2012.

$100 \mathrm{f}$.

Dissertação (Mestrado - Programa de Pós-graduação em Psicologia. Área de Concentração: Psicologia Clínica) - Instituto de Psicologia da Universidade de São Paulo.

1. Arte 2. Fenomenologia 3. Psicanálise 4. Hermenêutica I. Título.

NX152 
Nome: De Marchi, Sheila

Título: A arte como intermediador terapêutico para o desenvolvimento humano

Dissertação apresentada ao Instituto de Psicologia da Universidade de São Paulo para a obtenção de título de Mestre em Psicologia Clínica.

Aprovado em:

\section{Banca Examinadora}

Prof. Dr. Instituição:

Julgamento: Assinatura:

Prof. Dr. Instituição:

Julgamento: Assinatura:

Prof. Dr. Instituição:

Julgamento: Assinatura:

Prof. Dr. Instituição:

Julgamento: Assinatura: 
Aos meus pais, sempre.

À minha irmã, que tanto amo. 


\section{AGRADECIMENTOS}

Primeiramente gostaria de agradecer minha amiga e companheira de jornada, Fernanda de Paola, que esteve ao meu lado ao desbravarmos um caminho ainda desconhecido.

A toda a equipe do Caps-Unifesp, que acreditou neste projeto, em especial à Dra. Wilma Szarf Szwarc, coordenadora deste serviço, que possibilitou que ele acontecesse.

Ao MAM, por acreditar na importância da arte e possibilitar que ela faça parte da vida das pessoas.

Meu abraço carinhoso e gratidão a Daina Leyton, Karina Bacci, Leya Mira Brander e Renata Madureira por tornar a possibilidade de conhecer técnicas artísticas em realidade, principalmente a pessoas cujas realidades muitas vezes são dificilmente compreendidas, através de um trabalho profissional, cuidadoso e carinhoso.

Ao Prof. Dr. Andrés Eduardo Aguirre Antúnez por ter compreendido minha paixão pelo ser humano, por ter compartilhado seu conhecimento comigo, pela atenção e apoio durante o processo de definição e orientação deste trabalho.

Ao Instituto de Psicologia da USP, pela oportunidade de realização do curso de mestrado.

À Fundação de Amparo à Pesquisa do Estado de São Paulo, pela concessão da bolsa de mestrado e pelo apoio financeiro para a realização desta pesquisa.

Ao Prof. Dr. Cristiano Roque Antunes Barreira, Prof. Dr. Kleber Duarte Barreto e Prof. José Atílio Bombana por suas contribuições e conhecimentos que me ajudaram em minha investigação. 
Minha profunda gratidão a Daniela Batalha Trettel por sua paciência, leitura e, principalmente, amizade.

Ao Rodrigo Luiz Reganhan, que, ao meu lado, me trouxe conforto e apoiou este trabalho.

Agradeço principalmente aos pacientes que participaram desta jornada comigo. Sem vocês, nada disso seria possível. 


\section{RESUMO}

DE MARCHI, S. A arte como intermediador terapêutico para o desenvolvimento humano. 2011. 85 f. Dissertação (Mestrado) - Instituto de Psicologia, Universidade de São Paulo, São Paulo, 2012.

Este estudo trata do uso da arte como procedimento intermediário para o acompanhamento terapêutico de pacientes que frequentam um Centro de Atenção Psicossocial-. Para esta investigação focalizamos a experiência vivenciada com pacientes psiquiátricos em um curso intitulado Foto e Imagem, ministrado pelo Museu de Arte Moderna de São Paulo - MAM -, durante um ano e nove meses. Utilizamos como método de compreensão dos resultados clínicos observados através de análise fenomenológica a articulação com conceitos clínicos de Donald Winnicott e hermenêuticos de Gilberto Safra. Observaram-se mudanças comportamentais e psíquicas nos pacientes, tais como maior interação interpessoal naqueles distantes dos outros e com certa apatia; maior expressão verbal; retorno aos estudos e trabalho após anos de afastamento; melhora no relacionamento familiar, segundo os pais; aumento do interesse por atividades sociais. A aproximação das potencialidades de cada um dos participantes do curso foi possível a partir do reconhecimento de seu idioma pessoal e do sentido de sua existência a partir das produções fotográficas e artísticas realizadas. Esta perspectiva de trabalho terapêutico trata de um reposicionamento da clínica psicológica como elemento ético-ontológico, que possibilita à dupla profissional-paciente se sentirem enraizados na experiência humana. A arte permite ao indivíduo expressar-se, sem haver cobranças e expectativas; é vista como um meio de comunicação entre os indivíduos e para si mesmo. Através da arte pode-se auxiliar o indivíduo a lidar com a tensão ao relacionar a realidade interna à externa. $\mathrm{O}$ contato com a arte foi compreendida como uma experiência que pode ajudar o indivíduo a resgatar recursos adormecidos em seu Self, através do acompanhamento cuidadoso e atento de psicólogas, com a inclusão da família, no tratamento interdisciplinar em saúde mental.

Palavras-chave: Arte, fenomenologia, psicanálise, hermenêutica. 


\begin{abstract}
DE MARCHI, S. Art as an intermediary therapy for human development. 2011. 85 f. Dissertação (Mestrado) - Instituto de Psicologia, Universidade de São Paulo, São Paulo, 2012.

This work deals with the use of art as an intermediate procedure for therapeutic monitoring of patients attending a Psychosocial Care Center-Caps. For this research we focus on their experience with psychiatric patients in a course titled Photo and Imaging, taught by the Museum of Modern Art of São Paulo - MAM -, for one year and nine months. Used as a method of understanding of clinical outcomes through phenomenological analysis, coordination with clinical concepts of Donald Winnicott and hermeneutics of Gilberto Safra. Observed behavioral and psychological changes in patients such as increased interpersonal interaction in those distant from others, and with apathy, increased verbal expression; return to studies or work after years of absence; improvement in family relationships, according to the parents; increased interest as social activities. The approximation of the potential of each of the participants of the course was made possible through the recognition of their personal language and sense of personal existence, from photographic and artistic productions performed. This perspective of therapeutic work is a repositioning of clinical psychology as an ethical-ontological allowing dual professional-patient feel rooted in human experience. Art allows the individual to express themselves, with no demands and expectations, is seen as a means of communication between individuals and for himself. Through art we can help the individual to cope with the stress by relating internal to external reality. The experience of art was understood as an experience that can help the individual recover resources dormant in your Self, through careful monitoring and attention of psychologists, with the inclusion of family in interdisciplinary mental health treatment.
\end{abstract}

Keywords: Art, phenomenology, psychoanalysis, hermeneutic. 
SUMÁRIO

1. INTRODUÇÃO E JUSTIFICATIVA 10

$\begin{array}{ll}1.1 \text { OBJETIVO } & 19\end{array}$

2. PROGRAMA IGUAL-DIFERENTE 20

3. REVISÃO DE LITERATURA 22

4. FENOMENOLOGIA 26

5. PSICANÁLISE $\quad 34$

6. HERMENÊUTICA 39

7. MATERIAL E MÉTODO 43

8. RESULTADOS - DIÁRIO DE CAMPO 48

9. DISCUSSÃO

$\begin{array}{ll}\text { 10. CONCLUSÃO } & 76\end{array}$

$\begin{array}{ll}\text { REFERÊNCIAS BIBLIOGRÁFICAS } & 81\end{array}$

$\begin{array}{lr}\text { ANEXOS } & 84\end{array}$ 


\section{INTRODUÇÃO E JUSTIFICATIVA}

O presente trabalho visa discutir os benefícios do contato de pacientes diante de um curso de arte como um procedimento terapêutico e auxiliador no acompanhamento a pacientes tratados em Centro de Atenção Psicossocial Caps.

O interesse por este tema surgiu a partir da experiência obtida em curso de especialização em Psicologia da Saúde, no Departamento de Psiquiatria da Universidade Federal de São Paulo, quando apresentado um projeto assistencial ao Centro de Atenção Psicossocial desta instituição (Caps-Unifesp) ${ }^{1}$.

Um projeto foi elaborado e consistiu em oferecer aos pacientes uma atividade diferente das oferecidas pelo serviço na tentativa de ampliar suas possibilidades de desenvolvimento pessoal.

Os pacientes, usuários deste dispositivo para tratamento psiquiátrico, foram convidados a frequentar o Museu de Arte Moderna (MAM) sendo acompanhados por duas psicólogas. Os pacientes que participaram apresentavam melhora de seu quadro psicopatológico no momento da convocação, mas ainda apresentavam falta de iniciativa e dificuldade na sua reinserção social sem melhora em sua qualidade de vida.

Tendo em vista que o dispositivo Caps propõe a reinserção social e que estes pacientes apresentam, em grande parte, dificuldade em iniciar uma atividade externa a este ambiente de tratamento e mantê-la, pois a vinculação com um novo espaço exige maior cuidado e suporte, pensou-se no

\footnotetext{
${ }^{1}$ O Caps-Unifesp é o Centro de Atenção Psicossocial vinculado à Universidade Federal de São Paulo, onde se encontram pacientes psiquiátricos em tratamento interdisciplinar ambulatorial e intensivo. Conta em sua equipe profissional com médicos psiquiatras, psicólogos, terapeutas ocupacionais, assistentes sociais, técnicos de enfermagem, cozinheira e secretária.
} 
acompanhamento semanal dos pacientes participantes por psicólogas idealizadoras deste projeto assistencial. Com isso, pensou-se na criação de maior possibilidade de serem trabalhadas as dificuldades e os anseios que os pacientes costumam apresentar quando em contato com algo incomum em seu cotidiano, a arte.

Este acompanhamento também foi feito mensalmente por uma terapeuta ocupacional do Caps, juntamente com psicólogas, no primeiro ano do projeto, já que se tratava de um projeto piloto e nos auxiliava nas discussões.

Juntamente com o Museu de Arte Moderna (MAM) da cidade de São Paulo foi possível oferecer uma atividade com arte para estes pacientes, pelo projeto “Igual-Diferente”, o qual recebe subsídios de patrocinadores.

Tal programa disponibiliza cursos gratuitos dentro do ateliê, existente no complexo do museu, relacionados à arte para a população em geral e a pacientes de instituições de saúde, especialmente saúde mental, da cidade de São Paulo. Estes cursos são ministrados por artistas plásticos e fotógrafos profissionais contratados pelo museu.

O curso escolhido foi o denominado "FOTO e IMAGEM", devido ao tema, ao dia e horário disponível pela maioria dos pacientes do Caps-Unifesp e para as psicólogas que os acompanharam. O curso é anual e tem duração de oito meses (março a novembro, com férias em julho), sendo uma aula semanal de duas horas.

Os profissionais de saúde também participaram como alunos do curso, realizando as mesmas atividades, os mesmos direitos e deveres que os pacientes. Em outras palavras, não se estabeleceu uma diferença entre quem "trata” e quem 
“é tratado", já que ali não era um espaço para tratamento, e sim para aprendizagem e abertura para o conhecimento ampliado pela relação com a arte.

Neste curso são apresentadas técnicas de fotografia e de artes plásticas. As atividades são realizadas dentro do próprio ateliê ou externamente, no Parque do Ibirapuera, onde está inserido o MAM, de acordo com a proposta oferecida no dia.

No decorrer do tempo, este curso mostrou-se interessante para estes pacientes não só no âmbito da aprendizagem de uma atividade pela qual muitos se interessavam, mas também como treino para uma autonomia pessoal maior, para as possíveis elaborações de questões psicodinâmicas através da arte e para uma mais adequada reinserção social.

A preocupação com as questões acima se fez importante, pois elas foram observadas cotidianamente no local de tratamento durante o curso de especialização pelas profissionais como sendo pontos a serem investigados com os pacientes que estavam em tratamento psiquiátrico, principalmente, crônico. Ou seja, uma atividade extraCaps, num espaço físico diferenciado, com pessoas que não os tratariam enquanto pacientes, mostrou-se bastante importante como coadjuvante no tratamento interdisciplinar oferecido pelo Caps-Unifesp, pois, mesmo este não sendo o foco do curso, verificou-se diferenças comportamentais em pacientes dentro do espaço físico do Caps-Unifesp, que acreditamos serem em decorrência deste trabalho. No convívio com os pacientes observamos mudanças estas como: maiores interações entre pacientes, que se apresentavam "distantes" dos outros e até com certa apatia; pacientes que pouco se expressavam verbalmente começaram a expressar opiniões mesmo estas não sendo de consenso geral; retornaram aos estudos e trabalhos depois de anos de 
afastamento; melhoraram o relacionamento familiar descrito pelos pais; houve aumento do interesse por atividades sociais, entre outras situações que não eram observadas anteriormente.

A escolha do local e do "meio de comunicação" - a arte - ocorreu pelo fato de as idealizadoras do projeto acreditarem que a arte poderia ser um meio por onde questões do âmbito psicológico os mais primitivos pudessem ser examinados. Através da arte, pode-se investigar questões sensoriais, como as descritas por Safra (2005) - organização subjetiva do tempo, do espaço, da corporeidade, sonoridade - ajudando o indivíduo a constituir o seu self ${ }^{2}$. Constituição esta que, em decorrência das patologias instauradas nestes pacientes (psicoses e neuroses graves), sofreu prejuízos importantes. Além disso, pensa-se que a própria experiência artística, pura e simples, por si só, pode facilitar uma experiência constitutiva.

Para a constituição do self do indivíduo necessita-se muito do outro, de um ambiente suficientemente bom, do olhar, da recepção ao mundo, das atitudes do outro, para que ele consiga se diferenciar, tendo em vista que "desde sempre o ser humano é com o Outro ${ }^{3}$. Se o rosto do Outro não pode ser encontrado como acolhida ao mundo humano, a condição originária aparece como sofrimento infinito, agonia do anseio pelo Outro” (SAFRA, 2004, p.73).

Tendo isto em vista, o ambiente em que ocorreu o curso, as professoras, o acompanhamento psicológico aos pacientes até o MAM, mostrou-se um espaço

\footnotetext{
${ }^{2} \mathrm{O}$ "eu" conforme compreendido por D. W. Winnicott (1896-1971).

${ }^{3}$ Safra (2004) refere-se ao Outro em letra maiúscula como sendo o outro Sobórnost (terminologia que será discutida mais a frente), que implica ao mesmo tempo o contemporâneo, os ascendentes, os descendentes, a coisa, a Natureza, o mistério.
} 
potencial $^{4}$ para que o indivíduo pudesse vivenciar este contato com o outro e ser correspondido por ele, ao passo que as aulas foram realizadas em projetos grupais e individuais. As idas do Caps-Unifesp ao MAM foram acompanhadas por conversas entre as pessoas. No MAM, às vezes o paciente buscava sustentação emocional nas psicólogas, mas a produção de cada aluno era demonstrada, discutida com todos, elogiada ou se apontavam pontos para prestar mais atenção e melhorar.

Ao observar essas possibilidades, as acompanhantes incentivaram cada pessoa a fazer o percurso até o local da aula de modo independente, sem necessidade de se locomover até o ponto de encontro (Caps-Unifesp) ou ir diretamente para sua residência. O desenrolar desta mudança foi sendo observada de maneira cuidadosa; quando o aluno não atingia a proposta da aula e ele já tinha subsídios para tal, isto era apontado pelas professoras de maneira sensível e não permissiva, sendo paciente psiquiátrico ou não; havia regras durante as visitas frequentes às exposições realizadas no museu, que são estabelecidas pelas professoras e eram prontamente respeitadas.

Isso foi importante também para auxiliar no senso de autonomia e responsabilidade. Winnicott (2000, p.326) afirma que a mãe suficientemente boa “parte de uma adaptação quase total às necessidades de seu bebê, e com o passar do tempo adapta-se cada vez menos inteiramente, de acordo com a capacidade crescente do bebê de lidar com suas falhas”. De modo análogo, as psicólogas observavam despertares de potencialidades nos pacientes. Estes eram

\footnotetext{
${ }^{4}$ Conceito desenvolvido por Winnicott (1975) referindo-se a um lugar diferente do mundo interno e da realidade externa, mas que ocorre entre eles.
} 
estimulados e paulatinamente dependiam menos delas para irem ao MAM, exercendo assim mais autonomia.

A arte, neste contexto, pode servir como mediadora na comunicação com o outro, ao passo que, frequentemente, nos foram apresentadas e discutidas obras de artistas renomados, sua história, a época em que viveram, sempre relacionando com a temática da aula, com as técnicas aprendidas, com a atualidade, com a vida. E, a partir daí, foram realizadas nossas "produções artísticas” pela fotografia, tendo incentivo a prestar atenção na parte técnica, mas também em como transmitir a ideia que queríamos expor por meio da fotografia.

Através da arte, o indivíduo pode expressar sua criatividade que lhe é inerente e, com ela, buscar o sentido de sua própria existência. Tem a oportunidade de comunicar para o outro e para si suas emoções, seus sentimentos; e a possibilidade de encontrar mais uma via de simbolização. Esta última me parece especialmente importante, tendo em vista que

uma das tarefas fundamentais do ser humano é alcançar o registro simbólico de suas experiências, pois o registro simbólico dá ao homem a possibilidade de colocar sob o domínio do seu gesto os aspectos paradoxais de seu ser. (...) Simbolizar é importante não só para que significados se estabeleçam, mas principalmente por ser um processo de contínuas transformações de sentido em direção ao porvir. Importante ressaltar que o que estou chamando de registro simbólico não é o simples representar, mas colocar as questões fundamentais da existência em devir, por meio da ação criativa. (SAFRA, 2004, p.63)

A criatividade possibilita acontecimentos, gera eventos, cria o inédito no campo existencial. Safra (2006a, p.70) afirma que

o ato de criar é paradoxal, pois no momento em que o indivíduo cria um evento no mundo a sua criação mesma o desestabiliza, pois reposiciona o lugar em que ele se encontra anteriormente. Isto significa que para o ser humano é impossível criar um evento sem ser atingido, ao mesmo tempo, por este mesmo evento. Ao criar, o homem põe em questão a si mesmo. (...) A questão da criatividade se relaciona com o tema da liberdade, faceta que coloca o ser humano diante da responsabilidade do escolher, do decidir, do destinar-se. 
A criatividade é inerente ao ser humano, também pode mostrar-se importante quando dizemos que o fato de haver uma abertura para a compreensão do sentido das coisas, independentemente de questões psíquicas e intelectuais, auxilia o ser humano a responder a estes sentidos, a se apropriar de um "saber". Segundo Safra (2006a), este saber não é fruto da lógica ou da aprendizagem, mas surge da própria experiência de estar vivo, da experiência de beleza, da experiência de sofrimento.

Podemos reportar a fotografia como símbolo em sua função representativa, conforme descrito por Safra (op. cit., p.40), ou seja, "o símbolo como sinal que faz referência a um objeto ausente. Algo que pode ocorrer por meio da palavra ou pela imagem” e auxilia na integração do tempo e do espaço.

A psicanálise também se fundamenta por este conceito, pois ela preconiza que “a partir do momento em que o indivíduo pode suportar a ausência do outro, suportar a não satisfação do desejo, é que haveria o acesso à representação”. (Safra, op. cit., p.41).

Através do símbolo representativo, pode-se compreender o indivíduo em seu registro biográfico e na sua dinâmica pulsional. Opera-se pela lógica racional, o que pode nos auxiliar a dialogar e a "ajudá-lo a se situar frente às significações da sua vida psíquica e acompanhá-lo em seu processo de ressignificação de sua história”. (Safra, op. cit., p.56).

Durante as aulas, ocorriam "brincadeiras” feitas pelos participantes durante o seu fazer artístico, ao fotografar, desenhar, colar, pintar... Isso mostra quão prazerosas e significativas são estas atividades, deixando a "imaginação correr solta”, resultando em "pingos de água que se transformam em astronaves”, 
“copas de árvores que se parecem com brócolis”, “as paredes que, literalmente, têm ouvidos”, entre tantas outras coisas.

Neste momento, pensa-se o quanto o indivíduo está lidando com as suas ilusões, inerentes ao ser humano e que nenhum indivíduo jamais a resolve. (WINNICOTT, 2000). A ilusão se encontra em “um estado intermediário entre a incapacidade do bebê de reconhecer e aceitar a realidade, e sua crescente capacidade em fazê-lo” (WINNICOTT, op. cit., p.328), ou seja, está localizada na base dos primórdios da experiência do ser humano e que é inerente à arte, religião, imaginação e trabalho científico criativo na vida adulta.

Com isso, reflete-se na importância da arte como um intermediador capaz de atingir aspectos do ser humano que ele invariavelmente se depara e que podem lhe trazer um reconhecimento do sofrimento. Para Winnicott (op. cit., p.329), a aceitação da realidade é um processo que é realizado pelo ser humano e que

(...) jamais se completa, que nenhum ser humano está livre da tensão de relacionar a realidade interna à realidade externa, e que o alívio para esta tensão é proporcionado pela área intermediária de experiências, a qual não é submetida a questionamentos (arte, religião, etc.).

Pensa-se ser muito difícil tentar compreender o psiquismo humano, seu desenvolvimento, as questões subjacentes, sem contextualizarmos onde e em que época o indivíduo em questão está inserido, já que ele é afetado continuamente pelo mundo, por sua história, cultura, família.

Atualmente, talvez alguns seres humanos encontrem-se dispersos de si mesmo, tentando objetivar o subjetivo, “coisificar” experiências, se fragmentando. Isto facilita a promoção do sofrimento em decorrência da falta da constituição de si mesmo e do psíquico. Faz-se de suma importância poder 
auxiliar o ser humano a construir seu self, a poder reter e suportar sensações, sentimentos e percepções dentro de si.

Para Safra (2004), a presença do outro é fundamental para o ser humano, pois o recepciona no mundo e lhe oferta o cuidado que lhe possibilita $o$ estabelecimento do self, assim introduz a concepção de Sobórnost. Esta é uma noção do pensamento russo que se refere à ideia de unidade, conciliar, comunitário; e sua concepção é pensada em uma percepção ontológica, ou seja, está no cerne das “estruturas a priori que definem as possibilidades realizadas em cada existência humana” (nota de rodapé p.42), ou seja, cada ser humano é a singularização da vida de muitos. Em suas palavras (ibid, p.43-44)

Compreender o ser humano como a singularização da vida de muitos implica em dizer que cada ser humano é a singularização da vida de seus ancestrais e é o pressentimento daqueles que virão. ... o sentido de si é um fenômeno ontológico comunitário, isto é, acontece em meio à comunidade e como comunidade. Evento transgeracional, vindo da história em direção do futuro. A verdade de si mesmo acontece e se revela somente pelo reflexo do rosto do outro. Em nossa maneira habitual de pensar, o ser é constituído antes da comunidade, Sobórnost assinala-nos que o ser é comunidade!... Ele é a aparição dos ancestrais e é clareira do futuro, ele é único e múltiplo.

Ao contemplar a singularidade do ser humano, por meio da arte pode-se buscar, valorizar, olhar esta singularidade, o seu “eu”, sem necessariamente nomeá-lo, possibilitando assim uma diminuição do que Safra (2006) denominou de agonia do totalmente pensado ${ }^{5}$.

Neste trabalho, o método utilizado para compreender o que se revela nessa experiência clínica é o fenomenológico. Deixando-o em suspenso para analisar o

\footnotetext{
${ }^{5}$ Referência de seus analisandos frente ao mundo contemporâneo, "onde tudo é excessivamente nomeado e racionalizado, sem que seja levada em conta a dimensão do ser humano que está para além de qualquer possibilidade de conhecimento e para além de qualquer tentativa de apreensão da experiência humana, por excessiva nomeação” (p.20).
} 
Diário de Campo a partir dos conceitos de Winnicott e Safra, cujas experiências clínicas são acompanhadas do conceito de empatia de Edith Stein.

No campo hermenêutico, a partir do desenvolvimento de Safra, procurar-se-á refletir essas experiências à luz do idioma pessoal de cada paciente, compreendidos em seu modo de ser, a partir da semântica de seu estilo pessoal e singular que busca sentido para a existência humana.

Contribuições da fenomenologia são dadas por Bello (2004), que também descreve a unidade do ser humano em sua dimensão corpórea, dimensão psíquica e dimensão espiritual. Ou seja, ao observar, analisar, perceber o ser humano, é imprescindível olhá-lo em toda a sua magnitude e complexidade para poder apreendê-lo da maneira mais fidedigna possível.

Este projeto foi submetido ao comitê de ética da Universidade de São Paulo e aprovado em 26 de agosto de 2009, pelo Registro CEPH No 2009.033, onde a pesquisa clínica-teórica está sendo realizada.

\subsection{Objetivo}

O objetivo do estudo é refletir as experiências vividas no curso de arte intitulado "FOTO e IMAGEM" como intermediador terapêutico em um acompanhamento psicológico para pacientes psiquiátricos a partir do referencial fenomenológico, hermenêutico e psicanalítico. 


\section{PROGRAMA IGUAL-DIFERENTE}

O Programa Igual-Diferente visa estimular e orientar a produção e a apreciação artística para diversos públicos. Sua missão é promover o acesso a espaços culturais e às atividades neles realizadas, trabalhando a diferença para multiplicar as formas de conexão entre várias linguagens. As atividades são personalizadas e elaboradas de acordo com a demanda específica de cada grupo, a fim de proporcionar oportunidades para cada participante desenvolver o seu potencial criativo.

Por meio de parcerias com instituições de saúde, educação especial e projetos sociais, o Programa Igual-Diferente promove cursos regulares, oficinas e visitas a exposições. Pessoas com ou sem necessidades especiais, alunos com experiência ou iniciantes compõem os grupos de diversas atividades.

Dentre os inúmeros cursos que a instituição promove, optamos pela descrição apresentada no curso de fotografia que está em questão no estudo. Este curso é desenvolvido para iniciantes, com o intuito de possibilitar entrar em contato com o universo da fotografia, promovendo a construção de um repertório artístico através da fotografia. O objetivo é o desenvolvimento de um repertório artístico por meio de produções e apreciações de imagens, realizadas em aulas teóricas e práticas (as aulas teóricas são alternadas com saídas fotográficas, quando o aluno sai com a câmera para o Parque do Ibirapuera, para o museu onde está havendo exposições, para salas onde serão realizadas as fotografias e captura as imagens), nas quais os participantes trabalham os procedimentos básicos da fotografia e as modalidades: desenho, pintura, xilogravura e colagem. Tem como público-alvo 
usuários de serviços de saúde mental e o público em geral interessado em artes. (informação pessoal ${ }^{6}$ ).

${ }^{6}$ LEYTON, D. Comunicação recebida por e-mail em 01 out. 2009. Daina Leyton, coordenadora do Programa Igual-Diferente. 


\section{REVISÃO DE LITERATURA}

Foi realizada uma breve pesquisa em revisão de literatura, trabalhos atuais (de 1992 a 2010) que se refiram ao tema que está sendo proposto neste trabalho. Primeiramente, tal pesquisa ocorreu na base de dados Lilacs, Scielo e Cochrane, buscando pelas palavras arte, Caps e tratamento. Em decorrência da dificuldade em obter resultado esperado quando se buscava pelas três palavras simultaneamente, optou-se por combiná-las da seguinte forma: arte e Caps, arte e tratamento e Caps e tratamento. Outros fatores de seleção da escolha dos trabalhos foram realizados com a população adulta, pois a pesquisa se refere a uma população psiquiátrica em idade adulta, e por terem sido publicados nos últimos oito anos. Foram encontrados no total 181 trabalhos publicados, sendo 47, 3 e 131 em, Scielo, Cochrane e Lilacs, respectivamente. No entanto, apenas três deles se aproximaram ao objetivo proposto por esta pesquisa.

Posteriormente foi realizada uma pesquisa literária que estivesse em concordância com o tema e a teoria utilizadas neste trabalho, obtendo uma dissertação de mestrado e uma tese de doutorado.

Tavares (2003), em O papel da arte nos centros de atenção psicossocial-Caps, discorre sobre a abordagem artística nos cuidados desenvolvidos nos CAPS. Ele afirma que os dados obtidos através de uma pesquisa exploratória de campo de entrevistas com profissionais dos Caps indicam que atividades de base artística são utilizadas visando à interação positiva destes profissionais com os pacientes na reabilitação social dos pacientes. Com isso, conclui que os CAPS se utilizam da potencialidade criativa dos profissionais e usuários, sendo a arte tomada como uma estratégia do cuidar. 
Na perspectiva social, Martins, Barrezzi \& Ferreira (2009) descrevem, em A Inserção Social de Portadores de Transtornos Mentais Através da Arte, uma experiência empírica de pacientes de um ambulatório de saúde mental na cidade de Bauru (SP), na qual os grupos terapêuticos se utilizam de recursos artísticos diversificados, como música, desenho, pintura, literatura, consciência corporal e teatro. Através disso, corroboram com a ideia de que tratamentos alternativos buscam o sentido de valores humanos, possibilitando manifestações de valores e potencialidades nos pacientes, promovendo inserção social, cidadania e melhora na qualidade de vida, já que têm a possibilidade de expressar seus sentimentos e suas dificuldades de autoconhecimento e aumento da autoestima.

Castro (1992) utiliza em seu trabalho a discussão empírica de uma forma de arte, a dança, como possibilidade de ser um artifício de tratamento em Caps. Na população estudada de um Caps na cidade de São Paulo (de 1989 a 1991), observou-se que, através da dança, os pacientes se beneficiam da vivência do corpo inteiro numa perspectiva de autoconhecimento e expressão, desencadeando disposição para o lúdico, para a comunicação com o outro e para o conhecimento de si.

Em uma dissertação de mestrado intitulada A fotografia como instrumento de intervenção clínica junto a pacientes psicóticos, Andrade (2010) investigou, por meio de dois casos clínicos (pacientes esquizofrênicos em regime de internação), algumas das potencialidades do uso da fotografia como instrumento de intervenção clínica. Utilizou como referência teórica as contribuições de D.W.Winnicott, no que diz respeito aos conceitos de espaço potencial e função especular, sendo o ato fotográfico um procedimento interventivo-interpretativo, explorando suas facetas especular, apresentativo e icônica. Demonstrou que tal 
procedimento teve importante repercussão sobre a área do brincar criativo, imagem do corpo e o campo existencial do paciente.

Também utilizando-se do recurso fotográfico, mas juntamente com cartas, Mamede (2002), em sua tese de Doutorado, intitulada Cartas e retratos: uma clínica em direção à ética, desenvolve uma discussão a partir das complexas dificuldades encontradas no trabalho enquanto psicóloga da Colônia Feminina do antigo Manicômio Judiciário do Estado de São Paulo, apresentando uma proposta de clínica em direção à ética para o atendimento psicoterápico das pacientes internadas nessa instituição. A autora partiu inicialmente do conceito de consulta terapêutica desenvolvido por Winnicott, e, utilizando-se de fotografias e cartas, foi possível realizar as intervenções terapêuticas, possibilitando ajudá-las no resgate dos sentimentos de pertença, de dignidade, de inserção e, sobretudo, de constituição do self. Apesar disto, os objetos utilizados apresentaram limitações por não abarcar toda a clínica que estas pacientes demandam, restringindo-se ao início do renascimento ético. Para nortear as reflexões sobre o uso dos objetos, suas implicações e restrições, foram escolhidos quatro casos dentro da clientela em questão, que foram discutidos no cerne dos fundamentos teóricos de Winnicott e do filósofo Emmanuel Lévinas, do qual foi particularmente importante o conceito de ética, traduzida na responsabilidade que um ser humano deve ter em relação ao outro, entendido como presença transcendente.

Os trabalhos apresentados demonstram a importância do uso da arte no tratamento em saúde mental. Eles demonstram que a arte possibilita a interação entre os indivíduos, a reabilitação/reinserção social, a utilização de potencialidades dos pacientes, a expressão de sentimentos e de si, a busca por seu 
self; características que vão de encontro com os dados encontrados nesta investigação.

O que diferencia nosso estudo dos outros anteriores citados é que a proposta de ida ao MAM não apresenta função a priori terapêutica, pois é um curso teórico-prático. As aulas aconteciam em um espaço físico que não tinha a finalidade de ser um espaço para tratamento, mas um espaço social, para a comunidade. No curso, as psicólogas, mesmo sendo profissionais da área da saúde, que também tinham a função de tratar dos pacientes quando no Caps, no curso, eram também alunas. 


\section{FENOMENOLOGIA}

Esta corrente filosófica nos auxilia na reflexão da clínica psicológica a partir do estudo da Empatia (STEIN, 2004b), pensando na importância do Eu, do Outro, mas principalmente do Nós, dos acontecimentos vividos nos encontros humanos. O estudo da Empatia contribui com a pesquisa no que diz respeito à aproximação dos profissionais (cuidadores) para com os pacientes, ocorrida no decorrer do curso realizado no MAM, e, assim, podermos nos aproximar do outro em suas potencialidades e recursos.

Nos interessa na fenomenologia de Husserl, qual é o sentido da existência humana. Não busca explicar o ser humano, mas compreendê-lo, a partir de uma reflexão daquilo que se mostra. Segundo Bello (2004), Husserl teoriza sobre qual o sentido que o existir tem para o indivíduo. Com isso ele vai em busca da essência das coisas (redução eidética) e de saber o sentido das coisas (redução transcendental), não se atendo apenas à existência, mas ao sentido da existência para o homem.

Frente a isso, pode-se refletir sobre como ocorre a aproximação de duas pessoas (intersubjetividades), do profissional que cuida (psicólogo) e o paciente que é cuidado, onde se busca compreender o paciente e não explicá-lo.

A análise fenomenológica (BELLO, 2004) possibilita uma compreensão original aos distintos modos de estar e ser das pessoas. Muitos pacientes procuram encontrar no profissional-cuidador uma testemunha para suas aflições ou um interlocutor para auxiliá-los a alcançar um sentido para seu existir. Podemos pensar que a arte pode ser um intermédio para esta interlocução quando as palavras não podem dar conta do que precisa ser dito, ou revelado? 
Segundo Stein (2004b), o ser humano é um ser espiritual, capaz de transcender e partir do reconhecimento de si. Ele consegue reconhecer no outro o que ele tem de humano, dando-se então a sua capacidade de empatia, o que, portanto, é algo próprio da condição humana. Além do caráter da percepção humana, a empatia é o ato de apreender algo, de se dar conta, da vivência do outro.

A empatia como estudada por Edith Stein é um fenômeno de extrema importância para compreendermos a relação profissional-paciente, para apreender o sofrimento do outro e assim poder ajudá-lo em suas necessidades.

A estrutura da pessoa humana compreendida em sua forma tripartida e dinâmica corpo, psique e espírito contribui para ampliar os estudos em psicologia. A corporeidade é o que nos dá a constituição do ser que nos localiza. O corpo faz referência ao objeto físico e ao espaço. O espaço vivido está na base de todos os conceitos de espaço, distinto do espaço geométrico e idealizado da física (BELLO, 2004).

O registro dos atos do corpo é um terceiro momento, que supera a interioridade e a exterioridade, e possibilita ter consciência das coisas. Pode-se controlar o corpo e a psique, porém esse registro do ato de controle não é de ordem psíquica ou corpórea, mas de ordem espiritual (BELLO, 2004).

O estudo sobre empatia (ou entropatia) reposiciona o modo de estar com o outro, portanto possibilita outras formas de cuidados, pois demanda uma visão de homem peculiar. A partir da empatia e do que acontece neste registro, se desenvolve a intersubjetividade, o conhecimento de si e do outro, ou seja, a empatia é anterior às reações psíquicas de simpatia e antipatia. É comum no senso comum tratar empatia como simpatia, mas na fenomenologia de Husserl e 
Stein, a empatia é fundamento e encontro de subjetividades, é a maneira como o indivíduo é afetado pelo outro através da corporeidade, e a simpatia ou antipatia é uma reação psíquica.

O mundo contemporâneo mostra novas dificuldades que os seres humanos têm que enfrentar e considera-se que qualquer tentativa de diagnosticar uma pessoa gera um reducionismo de toda a potencialidade que é inerente ao ser humano. A partir de Edith Stein, o diagnóstico se volta à experiência vivida. Nesse sentido, todo e qualquer sintoma passa a ser mero coadjuvante diante da complexidade da condição humana, principalmente pelo vértice que este trabalho se propõe a discutir.

Husserl usava a palavra espírito porque na filosofia que o antecedeu, o que não era corpo era considerado da ordem da alma. Ele analisava a alma em duas partes: (a) uma formada por atos de caráter psíquico, cujo representante é o impulso psíquico não desejado ou incontrolável. Não somos nós as origens desses impulsos, nem nós que os provocamos, mas os encontramos. Se sentirmos um grande rumor, todos terão medo, e o medo não vem desejado por nós, ele é uma reação e acontece, essa é a parte psíquica; (b) a outra parte é a que reflete, decide e avalia, e está ligada aos atos da compreensão, da decisão, da reflexão, do pensar, sendo denominada de espírito. Todo ser humano tem potencialmente essas três características, umas mais, outras menos desenvolvidas. (BELLO, 2006).

Acreditamos que algumas de suas facetas podem ser explicitadas por meio da arte, tendo a possibilidade de ser vista, sentida ou reconhecida pelo outro. Esse trabalho mostra a importância de se ter alguém que os acompanhe 
para dar um sentido para a experiência vivida no MAM, no trajeto de ida e volta e, talvez, até mesmo nas atividades do curso em si.

Nesse sentido, pessoas que sofrem por apresentar transtornos psiquiátricos ou problemas psicológicos de tal magnitude que impedem as mesmas de trabalhar, estudar ou mais profundamente de encontrar um sentido para a vida parecem se aproximar da segunda dimensão (psíquica), sendo a terceira (espiritual) uma conquista ainda não pensada, acontecida, e que talvez se encontre em espera.

Pode-se pensar no desenvolvimento para se potencializar uma integração ou uma autodeterminação à terceira dimensão, a do espírito, pois, de acordo com Edith Stein (2004a), é possível ter acesso ao espírito através da educação e, como explicitado, uma das características do projeto com os pacientes do Caps-Unifesp é de participar de um curso de fotografia e imagem. O trabalho realizado no MAM é também educativo.

Através da educação, pode-se haver o autodirecionamento espiritual a partir do intelecto, da vontade, isto é, um processo cultural de desenvolvimento motivacional, tornando-se clara e integradora, utilizando-se da razão. Essa razão aberta à totalidade, portanto, constituída de totalidade (corporeidade e psiquismo) é sintetizada na palavra estética. Estética não é só corpo, não é só psique. Implica ambos os sentidos. A arte-educação estimularia a abertura expressiva a esse fluxo estético, à apreciação, ao aperfeiçoamento técnico, à expressão, ao reconhecimento do objeto e até à continência contida neste objeto, seu valor. Objeto, aqui, pode-se entender como a arte, como a fotografia. No entanto, para haver este movimento, isso implica que o indivíduo expresse a si mesmo no objeto, ou que um objeto "materialize” algo importante para si. Pode-se supor 
que o valor que o indivíduo dá para aquilo que ele está fazendo corresponde ao valor que dá para si mesmo. (informação verbal) ${ }^{7}$

Segundo Bello (2006) conhecem-se as três dimensões do ser humano (corpo, psíquica e alma) porque se tem Consciência, conceito fundamental em fenomenologia. A Consciência não é um lugar físico, nem um lugar específico, nem é de caráter espiritual ou psíquico. A Consciência é um ponto de convergência das operações humanas, que nos permite dizer o que estamos dizendo ou fazer o que estamos fazendo. Somos conscientes da realidade corpórea, da atividade psíquica e de uma atividade espiritual e temos consciência de que registramos esses atos. A distinção destes atos ocorre intuitivamente e todos os seres humanos têm esta mesma estrutura.

Nos aproximamos dos pacientes através da empatia, que é uma intencionalidade e orientação que conduz a um eu alheio. A intersubjetividade torna a vida comunitária, apesar de cada um permanecer na sua singularidade. Todo ser humano tem a qualidade de perceber, mas o que percebe e como percebe é absolutamente pessoal e singular.

A contribuição fenomenológica para a psicologia propõe reflexão das coisas físicas ou abstratas que se mostram e como se mostram. Atentar para a empatia é reconhecer que por meio dela que podemos nos comunicar ao receber a comunicação do outro.

Cada ser humano é examinado por suas características pessoais, ainda que haja uma estrutura comum a todos. Como dito anteriormente, o que interessa a Husserl é o sentido de existir, bem como o fato do ser humano ter facilidade para

\footnotetext{
${ }^{7}$ Anotações exame qualificação. Instituto de Psicologia. Universidade de São Paulo. 10 de junho de 2011.
} 
identificar sentidos para certas coisas e mais dificuldades para outras. Nem todas as coisas são imediatamente compreensíveis. Nesse sentido, quando uma pessoa está diante de nós, conseguimos acessar e compreender algumas de suas características, outras não (BELLO, 2006).

Nesta vertente, que une fenomenologia a esta maneira de cuidar dentro da perspectiva psicológica, a agonia relatada ao profissional é uma tentativa de encontrar um sentido para si. Não só a agonia falada, mas a demonstrada por meio da arte. E não só a agonia, mas qualquer outro sentimento, compreensão, pensamento que fale sobre o indivíduo.

O assunto e os fenômenos imagéticos estão presentes nas vivências entre o profissional e o paciente durante o encontro, fazendo parte essencial do campo intersubjetivo. Como a terapeuta manejará a situação clínica, dependerá da relação que estabelecerá com a pessoa no processo de continuidade e descontinuidade da condição humana.

Como a agonia, a raiva, a tristeza, a alegria ou tantos outros sentimentos são parecidos e comuns a muitos, os conteúdos são singulares. É isso que torna este encontro do psicólogo com o paciente um espaço peculiar para que o sujeito possa se encontrar, refletido no olhar do outro.

No estudo sobre os problemas da empatia, Safra (2006, p.46) comenta sobre Edith Stein:

Ela se propõe a fazer uma investigação fenomenológica do sentido de si, daquilo que se é como pessoa. Por meio desse caminho fenomenológico, Stein afirma que temos a memória de experiências que não vivemos diretamente. Ela mostra que há movimentos psíquicos, organizações de experiências alojadas em nós mesmos, que não realizamos por nós mesmos. Ou seja, há inúmeras experiências em nós mesmos que existem porque tivemos a possibilidade de acompanhar a experiência de uma outra pessoa. Edith nos oferece alguns exemplos: 'ao ouvir a descrição de uma cena repugnante vivida por alguém, podemos, pela forma como essa pessoa a descreve, viver 
uma experiência de repugnância que é fruto de um percurso em que nos deixamos levar, acompanhando o que esta pessoa nos apresenta a partir de sua sensibilidade'. É aqui que ela fundamenta o fenômeno da empatia.

Essas questões são discutidas por Stein para mostrar que, por meio do corpo, estamos continuamente acompanhando as experiências de outras pessoas. Somos frequentemente banhados pelas descrições plásticas e pelo modo como a corporeidade do outro nos atinge. É nesse fenômeno que Edith Stein fundamenta o fenômeno da empatia, bem diferentemente da compreensão meramente racionalizada ou excessivamente intelectualizada da vida humana.

Para essa autora a empatia é a possibilidade que temos de acompanhar o circuito da sensibilidade de um outro. Edith afirma que podemos acompanhar dois circuitos: o circuito da sensibilidade e o circuito da articulação do pensamento do outro. Jamais se alcança a experiência originária da sensibilidade do outro, assim como também jamais apreendemos pelo conhecimento quais seriam os motivos, os valores últimos de alguém. Podemos intuí-los, mas não saber desses valores diretamente. A possibilidade de acompanhar a expressão descritiva plástica ou o modo como a corporeidade do outro aparece permite que realizemos com o nosso próprio corpo o mesmo circuito descrito ou apresentado. Dessa maneira, podemos compreender os sentimentos dos nossos analisandos através do que nos apresentam, se também os acompanharmos por meio de nossa sensibilidade corporal. O nosso corpo nos fala por meio de imagens (a imagem refere-se a formas sensoriais que se desenham na corporeidade de uma pessoa) que são evocadas em nossa corporeidade pelo modo como o paciente se apresenta ... o analista intui o que se passa, não por telepatia, mas pelo fato de seu corpo estar sendo continuamente afetado pela forma de ser do paciente. (SAFRA, 2006, p.47-48)

O rigor fenomenológico enquanto método investigativo é útil ao processo de tratamento do sofrimento humano, pois possibilita conhecer uma pessoa a partir do sentido da sua existência em suas potencialidades e recursos.

Contudo, o fluxo estético necessita da consciência de algo para existir, portanto, pode-se pensar que se está atento à ordem do sensível, que não é irracional, que é dependente de um objeto sensível (arte, máquina fotográfica, técnicas fotográficas, direcionamento da aula, etc.), a um limite. Com isso, pode- 
-se pensar que esta experiência, portanto, pode ser vivenciada como terapêutica, pois, a arte, enquanto um ato expressivo e criativo, na qual o indivíduo pode ter a possibilidade de se (re)conhecer, valorizar, ter consciência de si, ela tem algo na ordem do "gratuito" e tem materialidade. A arte implica as três dimensões do ser humano (Stein, 2007). No corpo, a questão sensória; no psíquico, as atrações e/ou repulsões da atenção; e na dimensão espiritual, as tomadas de decisões e reflexões em cada ato fotográfico, em cada gesto, em cada ação, em cada proposta no curso. Isso possibilita não só um aprendizado, mas um processo terapêutico. 


\section{PSICANÁLISE}

A arte da psicanálise consiste nessa capacidade de compartilhar espaços mentais secretos e proibidos, de maneiras aceitáveis pela civilização, com a perspectiva de ampliar as potencialidades dos participantes, produzindo novos sentidos e tornando suas vidas mais criativas e significativas. É assim que ela participa da construção da mais importante e específica das características do humano: a subjetividade. (ROSSI, 2009)

No decorrer do curso realizado com os pacientes no MAM, algumas questões foram levantadas quando se refletia sobre as razões da importância da arte no ser humano, do acompanhamento até o local novo e - até então - desconhecido. Um dos pontos que auxiliava esta reflexão era a composição destas vivências com a teoria psicanalítica, com a reflexão sobre o self, espaço potencial e a criatividade, como postulados por Donald W. Winnicott (1896-1971).

Pensa-se na arte como um recurso terapêutico a ser utilizado, não como uma terapêutica conforme recomendações clássicas psicanalíticas, mas como uma nova possibilidade de o indivíduo se encontrar, encontrar seus sentimentos, o que não pode ser dito, auxiliando um “se colocar enquanto sujeito” em sua vida.

Rossi (2009), em seu artigo intitulado Arte e psicanálise na construção do humano, diz que Freud, assim como outros psicanalistas posteriormente, utilizou-se da arte como base para algumas de suas postulações teóricas. O autor aponta que, para Freud, a arte seria tanto uma fuga da realidade quanto "apoios 
para o pesado destino do homem civilizado” (Ibid.,p.25), ou seja, a arte poderia libertar, mas também ser usada como instrumento de submissão e como ferramenta para a manipulação das massas, tendo o "linimento ${ }^{8}$ artístico [...] poder curativo limitado [, pois] a pressão dos instintos, para ele (Freud), seria tão grande que jamais o prazer obtido pela descarga em natura das pulsões poderia ser superado por qualquer atividade artística ou cultural” (Ibid, p.26).

Mas, a partir de um grupo de psicanalistas britânicos, dentre eles, Winnicott, a arte passa a ser articulada como um novo espaço para a imaginação, a fantasia e a ilusão (ROSSI, 2009, p.27), no qual

o brincar passou a ser uma coisa muito séria e poder fantasiar e compartilhar fantasias fusionais em grande sintonia com uma mãe receptiva passou a ser considerado essencial para que alguém desenvolva a capacidade de sentir que a vida vale a pena.

Tal citação parece importante para o trabalho tendo em vista que, neste projeto, a todo momento foi-se pensando no curso de fotografia como sendo um "brincar", que dava possibilidade de se colocar enquanto sujeito, de lidar com seus anseios, emoções.

Com isso, a realidade factual perde importância para a capacidade de se construir uma visão criativa, tolerante, harmônica e benevolente do mundo e das relações afetivas, pois o espaço em que ocorrem os fatos ditos “objetivos” estão miscigenados e ocorrem ao mesmo tempo com a fantasia.

Pode-se dizer que o indivíduo é moldado pela realidade que lhe é apresentada, ao mesmo tempo em que molda sua vivência nela, a partir do uso,

\footnotetext{
8 "Medicamento untuoso, isto é, para fricções, destinado a acalmar dores." Dicionário Priberan da Língua Portuguesa. (2011). Recuperado em 09 de abril de 2011, de http://www.priberam.pt/DLPO/
} 
neste espaço virtual que se forma, de sua criatividade e fantasia, auxiliando, com isso, a construção de si, de um indivíduo, de um self.

Para Winnicott (1975), a capacidade de “brincar” é a capacidade de o indivíduo ter uma relação criativa no mundo, lhe é inerente, natural, ocorre em um espaço potencial (que não é nem o mundo interno do indivíduo, nem a realidade concreta e externa, é entre). E é "no brincar, e talvez apenas no brincar, que a criança ou o adulto fruem sua liberdade de criação (...) e é somente sendo criativo que o indivíduo descobre o eu (self)” (p.79-80).

Discutir-se-á neste trabalho sobre a possibilidade de a arte contribuir para a constituição do self.

Tendo em vista que o self pode corresponder à espontaneidade, à criatividade, à autenticidade, ao "saber qual é o desejo”, pensa-se que a arte pode ser um meio para ajudar a se ter acesso a essa dimensão psíquica do ser humano.

Para Winnicott, num nível mais primitivo, o que estrutura o ser humano é a crença da capacidade de reparação, ou seja, a ilusão de encontrar algo que busca, a ilusão de que é possível criar aquilo que se necessita. Podemos pensar nesta criação através da arte, onde o indivíduo pode apresentar certa liberdade para se expressar utilizando-se de sua criatividade e de sua ilusão.

Em sua obra Da Pediatria à Psicanálise, Winnicott (2000) diz que as ilusões são inerentes ao ser humano e que nenhum indivíduo jamais a resolve. A ilusão se encontra em "um estado intermediário entre a incapacidade do bebê de reconhecer e aceitar a realidade, e sua crescente capacidade em fazê-lo” (p.328).

Com isso, questiona-se a importância da arte como um intermediador capaz de atingir aspectos do ser humano que ele invariavelmente se depara e que podem lhe trazer um reconhecimento do sofrimento. 
Através da arte, o indivíduo pode expressar sua criatividade que lhe é inerente e, com ela, buscar o sentido de sua própria existência. Tem a oportunidade de comunicar para o outro e para si suas emoções, seus sentimentos.

Nesta forma de apresentação (arte), o indivíduo tem a oportunidade de exercitar sua onipotência criativa, de colocar em ação o seu gesto espontâneo, o que auxilia seu “transitar” psíquico, podendo haver mudanças neste, integrando-o, já que se utiliza de meios mais sofisticados, simbólicos de se comunicar.

Tendo em vista que, no presente trabalho, a população estudada são pacientes psiquiátricos, refletiu-se na compreensão que Winnicott (2000, 2005) tem sobre as formações psicopatológicas no indivíduo, como sendo estas uma grave falha ambiental num período ainda primitivo do desenvolvimento infantil. Juntamente com esta perspectiva e o fato desta psicanálise se basear no cuidado a partir de uma demanda da necessidade do paciente (WINNICOTT, 2005), compreendeu-se a importância da criação de um espaço e um tempo específicos para o auxílio do desenvolvimento do self no indivíduo. Este espaço se deu, no estudo, a partir do momento em que se criou um "grupo do curso de fotografia” e íamos todos juntos ao MAM. Esta modalidade de tratamento Winnicott (2005) nomeou de placement, ou seja, um lugar ofertado por um outro e que possibilite o processo de constituição do self.

Segundo Safra (2006b), em estudo intitulado Placement: modelo clínico

\section{para o acompanhamento terapêutico}

No placement o que se busca é a possibilidade de o indivíduo ser colocado em uma situação que corresponda às suas necessidades para que possa ser acompanhado em seu tratamento.[No entanto], ... não se trata de fornecer por meio do placement uma experiência emocional corretiva, mas da possibilidade de vir a se posicionar de forma diferente àquilo que houve. (SAFRA, op.cit., p.16-18) 
Com a familiaridade das profissionais presentes, por parte dos pacientes, questiona-se que isso possa ter contribuído para que um laço de confiabilidade, segurança se perpetuasse e facilitasse a possibilidade de uma ligação com o novo espaço em questão, o MAM. Isso, segundo Winnicott (2005), favorece a possibilidade de um desenvolvimento mais saudável do self. 


\section{HERMENÊUTICA}

Dentro da perspectiva de que através da arte o indivíduo tem a oportunidade de comunicar para o outro e para si suas emoções, seus sentimentos; e a possibilidade de encontrar mais uma via de simbolização, também será utilizado para o estudo o conceito descrito por Gilberto Safra, a hermenêutica ${ }^{9}$, denominada pelo autor de idioma pessoal ${ }^{10}$.

O autor busca uma outra forma de se colocar na sua prática clínica e de compreender o ser humano que não no campo do excessivamente nomeado e racionalizado. Para isso, ele se volta para o ethos e para a própria condição humana.

Safra (2005) pontua que a palavra e a linguagem discursiva não dão conta de todo o campo simbólico do ser humano.

O indivíduo apresenta o seu existir por gestos, por sonoridade, por formas visuais, por diversos meios disponíveis para constituir seu self e seu estilo de ser. São criações, na maior parte das vezes, de grande complexidade simbólica e não passíveis de decodificação.

(...) Há experiências que se expressam melhor pela linguagem discursiva, outras pelos símbolos orgânico-estéticos (...) [os quais] veiculam o sentir, o ser e o existir (...) [e por isso], podemos dizer que eles não representam, mas apresentam, e abrem uma determinada experiência de sentir, existir ou ser. (p.24-27)

\footnotetext{
9 “Hermenêutica é a arte de interpretar o sentido das palavras, das leis, dos textos" (SAFRA, 2006). Vale ressaltar que hermenêutica é um termo que vem da filosofia. Provém do grego "herméneuein", que significa "declarar", "anunciar", "interpretar", "esclarecer", "traduzir", ou seja, algo que é "tornado compreensível" ou "levado à compreensão". Ou ainda derivado do grego "erméneutiké", significando "ciência", técnica". (http://pt.wikipedia.org/wiki/Hermen\%C3\%AAutica. Acesso em 02 de maio de 2012).

10 "Maneira pela qual a singularidade do ser humano aparece em seu modo de ser, em seus gestos, em sua linguagem e em seu estilo pessoal” (SAFRA, op.cit., p.20)
} 
Neste trabalho, o autor se detém a um tipo de símbolo estético, os símbolos de self, os quais se articulam em imagens, objetos recortados na materialidade, apresentando os enigmas da vida do indivíduo e também seu estilo de ser.

Com isso, pode-se refletir que a expressão simbólica não é exclusivamente feita pelo verbal e que a singularidade do ser humano pode ser buscada, valorizada, olhada, sem necessariamente ser nomeada.

No trabalho proposto aqui, observa-se a importância desta forma de se apresentar no mundo, através da arte.

De acordo com Safra (2006a), o homem, sendo ontologicamente um ente em precariedade, está sempre aberto à compreensão do ser e busca responder às questões da sua origem e de seu fim.

Se a forma de se inscrever no mundo não pôde ser realizada pela comunicação com alguém significativo, certamente tenderá a acontecer de forma impulsiva e desorganizada, expressando o desespero sem nome, vivido pelas pessoas que não tiveram aqueles acontecimentos em suas vidas. Ao lidar com humanos, estamos diante de seres que buscam intensamente, com os meios disponíveis, a possibilidade de humanizar-se (SAFRA, 2006). Assim, todo ser humano necessita acontecer no registro singular e coletivo, isso é fundamental na realização do si mesmo. Na ausência de um desses registros, há um sofrimento pela vivência de não existência e de não realização de si.

Por meio da arte podem-se evidenciar as questões sensoriais, como descritas por Safra (2005), a organização subjetiva do tempo, do espaço, da corporeidade, da sonoridade, ajudando o indivíduo a constituir o seu self. Acredito que a constituição sensorial pode ter sofrido prejuízos importantes diante da decorrência das psicoses e neuroses graves. 
Para a constituição do self de um indivíduo, necessita-se muito do outro, do ambiente suficientemente bom, do olhar, da recepção ao mundo, das atitudes do outro, para que ele consiga se diferenciar, tendo em vista que, "desde sempre o ser humano é com o Outro. Se o rosto do Outro não pode ser encontrado como acolhida ao mundo humano, a condição originária aparece como sofrimento infinito, agonia do anseio pelo Outro” (Safra, 2004, p.73).

Mas para esta busca de si, com o Outro, o indivíduo utiliza-se da sua criatividade - que lhe é constitutiva -, possibilitando acontecimentos, gerando eventos, criando o inédito no campo do psíquico, do existencial.

Compreende-se que esta criatividade inerente ao ser humano também pode mostrar-se importante quando dizemos que o fato de haver uma abertura para a compreensão do sentido das coisas, independentemente de questões psíquicas e intelectuais, auxilia o ser humano a responder a estes sentidos, a se apropriar de um “saber”. Segundo Safra (2006a), este saber não é fruto da lógica ou da aprendizagem, mas surge da própria experiência de estar vivo, da experiência de beleza, da experiência de sofrimento.

Podemos nos reportar ao símbolo em sua função representativa, conforme descrito por Safra (2006a), ou seja, “o símbolo como sinal que faz referência a um objeto ausente. Algo que pode ocorrer por meio da palavra ou pela imagem” (ibid, p.40) e auxilia na integração do tempo e do espaço.

Há pacientes que se sentem adoecidos pelas perspectivas racionalistas e iluministas que norteiam, segundo Safra (op.cit., p.16), "grande parte das teorias em psicologia e organizam o mundo em que vivemos”. Ele cita uma passagem da obra A estrutura da pessoa humana de Edith Stein que indica um distinto modo de compreender o outro ser humano: 
Se o conhecimento é uma captação espiritual de um ente, é lícito dizer que conhecemos o modo de ser próprio de um homem: este modo de ser nos mostra através de múltiplas formas expressivas nas quais o "interior" se "exterioriza” e nós compreendemos essa linguagem. O modo de ser próprio de uma pessoa se expressa em formas que podem seguir existindo separadas dela: em sua letra, no estilo que se reflete em suas cartas ou em outras manifestações literárias, em todas as suas obras, e também nos efeitos que produziram em outros homens. (SAFRA, 2006a, p.16-17)

Safra (2006a) mostra a importância de trabalharmos na intuição e na compreensão empática, não como funções mentais, mas como funções corporais, já que se intui e se cria empatia por meio de nossa sensibilidade.

Juntamente com esta perspectiva empática, pode-se pensar a amizade, e até mesmo a solidariedade, como uma questão ética do ser humano, mas, para a psicanálise tradicional, isso não é visto com bons olhos, pois não compreende o ser humano como um ser ontológico. Porém, com a discussão feita neste trabalho, observa-se que esta compreensão do ser humano individual, mas ao mesmo tempo em comunhão com a condição humana, foi um facilitador no decorrer do processo, pois tanto as psicólogas quanto os pacientes estavam na mesma condição humana no momento do percurso e do curso no MAM.

Um outro ponto de extrema importância, além do ontológico, é o reconhecimento do seu idioma pessoal para contemplar a singularidade do ser humano. Isso é fundamental para o sucesso terapêutico, do cuidado, pensar esta singularidade ao planejar a proposta terapêutica, o lugar (placement), o que irá ser realizado. 


\section{MATERIAL E MÉTODO}

Trata-se de uma pesquisa qualitativa, a qual não se utiliza de um modelo único de técnicas exclusivo e estandardizado, pois parte do pressuposto que as ciências humanas têm sua especificidade e que o pesquisador pode optar por descrever o ser humano de acordo com o seu momento e sua cultura, porém ele deverá expor e validar os meios e as técnicas adotadas, demonstrando cientificidade dos dados colhidos e dos conhecimentos produzidos. (CHIZZOTTI, 1988).

No método qualitativo, trabalha-se com a compreensão dos fenômenos, com aquilo que se mostra, que se manifesta à consciência, que pode ser trazido à luz (MARTINS e BICUDO, 1990). Segundo Turato (2003), esta metodologia tem como principal base filosófica a fenomenologia.

Para descrever a experiência vivida no curso de "FOTO e IMAGEM" ministrado por artistas plásticos e fotógrafos do Museu de Arte Moderna de São Paulo utilizamos aquilo que se revela à consciência (fenomenologia), verificando o potencial terapêutico (psicanálise winnicottiana) e um conhecimento a partir do registro comunitário (clínica ontológica de Gilberto Safra).

Foram analisadas as oficinas realizadas, nas quais, tanto a pesquisadora, quanto os pacientes em tratamento no Caps-Unifesp participaram. Focou-se nas observações feitas pela pesquisadora diante dos acontecimentos, das evoluções e dos dados desta atividade. Ou seja, os resultados da pesquisa foram a partir das observações da experiência vivida pela pesquisadora, buscando ampliar as elaborações, tanto nas oficinas no MAM quanto nas observações de mudanças 
comportamentais e emocionais ocorridas nos pacientes e relatadas em um diário clínico.

Foi elaborado o Termo de Consentimento Livre e Esclarecido ${ }^{11}$ (ANEXO 1) e entregue aos pacientes em tratamento no Caps-Unifesp participantes do curso “FOTO e IMAGEM” em 2007 e 2008.

Os pacientes não foram identificados, apenas citados alguns dados como sexo, idade, transtorno psiquiátrico diagnosticado e vinhetas clínicas, quando se fez necessário para o contexto do trabalho.

Por ser uma observação já realizada nos anos de 2007 e 2008, os dados ou resultados foram resgates mnêmicos das experiências vivenciadas pela pesquisadora e registrados em um diário de campo.

A atitude fenomenológica da pesquisadora permitiu olhar para o campo da arte visando conhecimento, descoberta, relacionando com o desenvolvimento psíquico humano e com sua experiência profissional, esforçando-se para alcançá-lo de modo não preconceituoso, conforme a redução fenomenológica orienta. Ou seja, buscou-se a redução eidética (redução à essência) e, posteriormente, a redução transcendental (redução ao sujeito), através da análise das vivências, seguindo os passos do método de Husserl, e realizando uma descrição qualitativa dos atos e das vivências (BELLO, 2004).

Stein (2007) descreve como o princípio mais importante do método fenomenológico o de fixar a atenção nas coisas mesmas. Isso quer dizer que não é apenas apreender as coisas, os momentos, pelo empirismo, mas dirigir a

\footnotetext{
${ }^{11}$ O projeto foi aprovado pelo comitê de ética da Universidade de São Paulo, pelo Registro CEPH N 2009.033, em 26 de agosto de 2009.
} 
atenção para o essencial, abordar as coisas com um olhar livre de preconceitos e “beber” da intuição imediata ${ }^{12}$.

Para Husserl, a intuição é uma percepção espiritual que reside em toda experiência particular como um fator que não pode faltar, que é universal e que é ‘inseparável da experiência particular e é afetada por si mesma’ (STEIN, 2007).

Através da análise fenomenológica, torna-se possível evidenciar a dimensão psíquica, isolando-a para estudá-la por si mesma, mesmo sabendo que na vida concreta é impossível separar a psique do corpo. "Por isto, se quisermos examinar o que é psíquico, necessitamos fazer uma reflexão e pela reflexão, temos consciência das vivências, pois estas têm a característica de serem intencionais” (BELLO, 2004, p.108-109). Além disso, por esta perspectiva, torna-se possível alcançar os níveis do corpo, da psique e do espírito através das vivências, possibilitando, com isso, adentrar na interioridade do sujeito, entender como ele é constituído. Em outras palavras, “escavar” a subjetividade humana, colocando em evidência seus significados.

Tendo em vista que o objeto da psicologia é o ser humano, a análise visa à estrutura do ser humano, assim Husserl denominou a psicologia

\section{fenomenológica:}

A psicologia fenomenológica é a descrição do conjunto da estrutura psíquica do homem, pois Husserl pensava em poder oferecer, através desta psicologia fenomenológica, a base para uma psicologia como ciência. ... [Além disso, pode aplicar-se também] no plano empírico, sendo que essa aplicação leva à exatidão, ou seja, à elaboração de conceitos descobertos de maneira verdadeiramente rigorosa e válida”(BELLO, 2004 p.104-121).

\footnotetext{
${ }^{12}$ A autora assinala que 'a intuição não é somente a percepção sensível de uma coisa determinada e particular, assim como é aqui e agora. Há uma intuição de que as coisas são por essência, e isso pode ter, por sua vez, um duplo significado: de que a coisa é por seu ser próprio e o que é por sua essência universal'. (p.33). [tradução nossa].
} 
A pesquisadora levou em conta sua própria experiência no decorrer do curso, pois, segundo Bello (op.cit, p.53)

"Entre todas as vivências que cada um de nós está vivendo neste momento, nós não podemos conhecer as que estão ocorrendo nos outros, mas apenas aquelas que estamos vivendo em nós. Todavia, nós podemos entender um pouco o que os outros estão vivendo, pois nós temos a possibilidade de ver a expressão do rosto e a atitude do corpo. Conseguimos captar o que os outros estão vivendo, pois nós podemos viver as mesmas coisas, mesmo que não seja neste instante.”

Podemos entender o que as outras pessoas estão vivendo por meio de suas falas e produções, sejam elas artísticas ou não, pois, segundo o método fenomenológico, deve-se captar o sentido da essência das coisas (redução eidética).
A análise fenomenológica do perceber supera o plano da percepção e atua no nível de uma outra vivência que é a reflexão. (...) A fenomenologia (...) trata de analisar, mais do que partir de conceitos, princípios e deduzir. Não se parte da consciência, mas, por exemplo, da percepção e daquilo que está por baixo da percepção, chegando ao corpo, à psique e ao espírito. (BELLO, 2004, p.90-100)

Como podemos ver também dentro do campo da filosofia, em contato com a psiquiatria, no âmbito da psicopatologia, temos Minkowski (2000), ao examinar um paciente (e aqui se pode compreender também ao examinar uma situação, um momento), não se utiliza apenas do método das ciências naturais, com enumeração das reações presentes, análises e classificações, mas o examinador deve também deixar-se guiar por sua própria intuição, ou seja, levar em conta também o ponto de vista psicológico, sua afetividade e sentimentos.

Após a coleta dos dados e da escrita do diário de campo, o método fenomenológico foi suspenso para que fossem articulados os conceitos clínicos de Winnicott, Safra e Edith Stein. 
Usamos as concepções de Winnicott sobre a importância da ilusão na constituição psíquica, do ambiente suficientemente bom e do potencial criativo da natureza humana.

No pensamento desenvolvido por Gilberto Safra, buscou-se compreender as pessoas em seu idioma pessoal, de uma clínica ancorada na relação, no encontro humano e na comunidade de destino. 


\section{RESULTADOS - DIÁRIO DE CAMPO}

Este diário de campo foi escrito de maneira retrospectiva, coletando informações de minha memória, minhas anotações, visualizando o resultado dos trabalhos realizados (os quais eu possuía, já que as professoras deram para mim e para minha colega de projeto um DVD com todas as fotos tiradas, dos dois anos) e de conversas posteriores com esta colega, parceira de projeto.

Nesta escrita não identificarei os alunos pelos nomes, apenas através de iniciais quando julgar necessário para melhor compreensão do texto; não pretendo expor o diagnóstico psiquiátrico dos pacientes, pois para mim o mais importante é o sujeito, seus comportamentos e sentimentos, e não a doença. Utilizarei a denominação “paciente” quando me referir às pessoas que fazem tratamento psiquiátrico no Caps-Unifesp. A fim de exemplificar a experiência com eles vivida, apresentarei relatos de alguns pacientes quando julgar oportuno.

Será realizado o relato do "primeiro ano” do curso e do "segundo ano”, identificando-os durante a descrição quando se fizer pertinente.

A ideia de realizar um projeto com os pacientes do Caps-Unifesp se deu a partir de um incômodo meu e de uma colega, psicóloga, que frequentava curso de especialização comigo. Estávamos no último ano da especialização em Saúde Mental do Departamento de Psiquiatria da Unifesp e nosso último estágio ocorria no Caps desta instituição. Dos serviços pelos quais estagiei, o Caps, minha colega e eu já tínhamos mais intimidade com o local, com alguns dos pacientes, com os profissionais que lá trabalhavam e com o trabalho em si. Estávamos mais à vontade e conhecíamos um pouco mais sobre saúde mental, suas possibilidades e alguns limites. O estágio durou mais 4 meses corridos de “imersão” no serviço. 
Neste tempo de convivência com o trabalho realizado no Caps-Unifesp percebemos que muitos pacientes ficavam deitados no sofá, fumando no quintal ou dormindo, e não participavam das atividades terapêuticas propostas, mesmo com o incentivo do corpo profissional. Além disso, era um tanto comum observarmos uma regressão no quadro patológico de pacientes quando passavam para um estágio no qual o acompanhamento ou o tempo que permaneciam no espaço físico do Caps-Unifesp diminuía. Ou seja, quando passavam do tratamento intensivo (acompanhamento diário) para o semi-intensivo (comparecimento no Caps-Unifesp apenas alguns dias na semana, em alguns grupos terapêuticos), ou do semi-intensivo para o ambulatório (participação em grupos de medicação e, eventualmente, um ou outro grupo terapêutico semanal), alguns pacientes apresentavam recaídas sintomatológicas que já haviam superado. Sabe-se que nos quadros psiquiátricos pode haver “crises” e o retorno de alguns sintomas, necessitando de acompanhamento mais intenso ou até mesmo de internação psiquiátrica, porém era comum isso acontecer quando ocorriam as mudanças terapêuticas de tipo de intervenção (intensivo, semi-intensivo ou ambulatorial). Estou levando em conta neste relato que não houve mudança ou diminuição na ingesta medicamentosa destes pacientes.

As experiências obtidas em um curto período de estágio ilustraram também as dificuldades que se estabeleciam no percurso de um encaminhamento à possível vinculação com um novo ambiente, principalmente quando os pacientes apresentavam melhora sintomatológica e um plano terapêutico que envolvia um encaminhamento para cursos, atividades que eles verbalizavam ter interesse. De modo geral, os pacientes apresentam dificuldades em iniciar atividades externas 
ao Caps, fato comum na socialização de pacientes psicóticos e neuróticos graves, que apresentavam dificuldades na inserção e manutenção de novas atividades.

Com isso, refletimos sobre o lugar em que estas pessoas se colocavam ou se reconheciam. Pareceu-nos que talvez não existisse, pelo menos não o suficiente, o reconhecimento de si enquanto indivíduo, enquanto pessoa, mas sim enquanto paciente, passivo. E que talvez, até mesmo dentro da família, do meio em que vivem, também tivessem este tipo de reconhecimento. Ou então que talvez só se sentissem reconhecidos em um lugar de tratamento?

Se esta suposição estivesse correta, como iríamos incentivá-los a um retorno à vida social, ao trabalho, aos estudos, ao lazer? Como incentivar a uma autonomia que os auxiliasse a enfrentar os percalços da vida, as dificuldades do dia a dia? Estes pacientes iriam ser apenas pacientes e nunca mais sair do Caps? Mas também o Caps não tem a proposta de um tratamento que englobe o indivíduo como um todo e que o auxilie a uma reinserção social? Como fazer isso com pessoas que parecem não querer (ou conseguir) sair de uma posição passiva?

Enfim, os questionamentos eram muitos diante da observação que fazíamos e pensamos em, ao terminar o período de estágio, apresentar uma proposta ao Caps-Unifesp. Neste projeto inicial poderíamos ver se conseguiríamos auxiliar estes pacientes a terem certa autonomia na vida, a poderem experimentar uma vivência além dos muros do Caps e de sua casa, a terem contato com pessoas que os vissem enquanto seres humanos, pessoas, e não se “eram” “esquizofrênicos”, “bipolares”, “borderlines”, “depressivos”, ou qualquer outro rótulo dentro do espectro classificatório dos transtornos mentais. 
Ainda no processo de elaboração do projeto, cogitamos levar os pacientes ao MAM, posto ter um funcionário do museu nos informado, meses antes, que lá existiam cursos gratuitos abertos à população e que buscavam pessoas que não tinham muito acesso à arte e à cultura, inclusive aquelas que realizavam tratamento psiquiátrico.

Após nossas indagações, fomos até lá verificar do que se tratava. Conversamos com a coordenadora do Projeto Igual-Diferente, Daina Leyton, que nos apresentou os cursos oferecidos, a proposta, os horários, as vagas e a possibilidade de fazermos uma parceria, assim como alguns hospitais psiquiátricos e outros Caps. Havia também a oportunidade de esta parceria ser mantida nos anos seguintes, com vagas preferenciais aos pacientes do Caps-Unifesp. Além disso, a pedido do MAM, foram realizadas reuniões semestrais com a equipe do projeto do museu e outros parceiros, para uma avaliação da repercussão que as oficinas propagam no contexto do Caps-Unifesp e nos outros serviços, e se havia maneiras de aprimorar os cursos oferecidos.

Próximo do término do nosso curso de especialização no final do ano de 2006, com um sentimento de vazio e abandono se aproximando - já que não teríamos mais “nossas 40 horas semanais preenchidas” - e, o mais forte de tudo, o desejo de poder continuar em um lugar que gostávamos de estar, fazendo o que achávamos importante, com pessoas que julgávamos que teriam muito mais a contribuir além de fazer seu tratamento, retornamos ao nosso estágio no Caps-Unifesp com muitas ideias, que foram amadurecendo com o tempo. Reunimo-nos para delinear o projeto, a sua importância, o que poderíamos oferecer terapeuticamente e que ao mesmo tempo não fosse configurada uma atividade terapêutica clássica, tradicional - já que isso os pacientes já tinham no Caps. 
Ao término do curso de especialização, em janeiro de 2007, oferecemos um projeto e discutimos com a coordenadora ${ }^{13}$ do Caps-Unifesp nossa proposta e apresentamos este projeto em uma reunião de equipe na qual estavam presentes todos os profissionais da equipe fixa do Caps-Unifesp, o qual foi bem aceito e frisado por parte de alguns destes profissionais a importância que este teria, já que não conseguiam, por falta de tempo, monitorar mais de perto os acompanhamentos externos que faziam.

Nessa mesma reunião com a equipe do Caps pedimos para que pudessem avaliar o benefício da inserção dos pacientes nessa atividade, assim como o cuidado de avaliar a indicação caso a caso. Com a aceitação de todos os membros da equipe, fez-se novo contato com o MAM para acerto do contrato e informações finais.

Finalmente, na manhã do dia 15/02/07, marcamos uma reunião com os pacientes que nós e a equipe identificamos como potenciais beneficiários do curso e da proposta oferecida. Na apresentação frisamos que a participação nesse curso não era obrigatória, que não tinha o intuito terapêutico tradicional, mas sim de aprender uma nova atividade, novas técnicas fotográficas, e que as professoras não eram profissionais da área da saúde, mas artistas plásticas e fotógrafas. Comunicamos as informações que tínhamos sobre o curso, como a localização, a duração, o período de férias, como eram as aulas e seu horário, que se usavam máquinas digitais, que iríamos aprender técnicas de fotografia como o uso da luz, a função da máquina a usar, ângulos, intervenções, etc.

\footnotetext{
${ }^{13}$ Dra. Wilma Szarf Szwarc, a quem agradecemos a autorização para viabilizar o projeto e refletí-lo nessa investigação strictu-sensu.
} 
Outra questão apresentada como de extrema importância para os pacientes era a de que o MAM havia disponibilizado 20 vagas para o Caps e o restante para outros públicos interessados que não fosse do Caps-Unifesp. Destas 20 vagas, uma seria para mim, uma para minha colega de projeto e 18 para os pacientes interessados ou até mesmo os familiares que quisessem participar. Com isso, eles teriam que se comprometer com a assiduidade para que não "pegassem a vaga de outra pessoa”.

Foi apresentado desde o início que o percurso de ida e volta seria realizado com o transporte fornecido pelo hospital e com o acompanhamento das psicólogas.

Gradativamente o transporte seria modificado pelo transporte público, havendo a possibilidade de os pacientes optarem pelo percurso desejado de acordo com a própria conveniência.

Pensamos o projeto desta maneira, pois consideramos que estes processos proporcionam desenvolvimento de compromisso e autonomia, no qual cada participante poderia repensar seu horário, não deixando de comparecer ao compromisso e progressivamente construindo a própria autonomia. Este percurso se asseguraria na continência do acompanhamento, e a permanência do paciente na construção de possível nova conduta. Vale ressaltar que o espaço do MAM contribui para esse processo por estar inserido no parque do Ibirapuera e, portanto, favorecer aos pacientes a circulação interna neste ambiente, pois é um espaço aberto, amplo, arborizado, público e com possibilidades de entrar em contato com exposições de artistas famosos.

Na reunião com os pacientes, as preocupações apresentadas por eles foram: e se eu não quiser continuar? Por que ir de ônibus público e não com o 
transporte do hospital para sempre? E se eu não me sentir bem? Mas por que eles não vêm até aqui no Caps para dar as aulas?

Frente a esses questionamentos, buscamos mostrar a eles como estavam “grudados” ao Caps-Unifesp; que queriam receber, mas não dar; que estavam acomodados; que colocavam empecilhos para não ir ou não continuar; que seria importante eles saberem ir e vir ao MAM, que ônibus pegar.

As psicólogas informavam aos pacientes que, caso não gostassem ou quisessem desistir, poderiam conversar sobre isso antes de desistirem. O que achávamos contraindicado era continuar no curso e não comparecer, pois não era uma atividade obrigatória. Gostar ou não do curso poderia ser experimentado já nas primeiras aulas e ainda poderia haver tempo de disponibilizar a vaga a outra pessoa interessada, que não perderia muitas aulas. Além disso, caso ocorresse uma eventualidade e precisassem faltar, foi acordado com os pacientes que teriam que nos avisar antecipadamente. Porém, dissemos que eles não precisariam dar a resposta naquele dia, que era importante refletir e que iríamos ter mais dois encontros nas duas semanas seguintes, no mesmo horário, para falar deste curso, tirar dúvidas e para se acostumar com a ideia.

A maioria dos pacientes gostou da proposta de ser um curso de fotografia e, mesmo alguns estando um tanto receosos, aceitaram participar.

No projeto também foi contemplada a importância da participação dos familiares enquanto incentivadores ou não da posição passiva dos pacientes. Por isso, no decorrer do ano de 2007 realizamos cinco reuniões com os familiares inseridos no programa. Os pacientes foram informados dessas reuniões e pedimos para que falassem em casa sobre o curso, as reuniões e que os membros 
da família poderiam também ir ao curso se tivessem interesse. Ainda assim, buscamos comunicar por telefone o convite às reuniões familiares.

Estes encontros com a família tinham o propósito de integrá-los nesse projeto e ter maior conhecimento das ressonâncias destas atividades, além de informá-los quanto ao conteúdo do curso oferecido. Durante o período de 8 meses no estágio da especialização, pudemos observar que, mesmo diante das iniciativas positivas advindas dos pacientes, suas famílias geralmente reagiam com estresse e insegurança, podendo prejudicar tanto o desenvolvimento no tratamento, como na vinculação a ambientes externos. Para tanto, promovemos esses encontros para que houvesse maior parceria com essas famílias, e para melhor auxiliá-las neste contexto. Tais reuniões foram agendadas assim: antes de iniciar o curso, um mês após o início do curso, uma semana antes das férias, um mês após o retorno das férias e uma semana antes do término do curso. As duas primeiras reuniões seriam realizadas apenas com os familiares, havendo a possibilidade da inserção dos pacientes nas demais. Esta decisão foi tomada para que na primeira reunião pudéssemos passar as informações para os familiares as quais seriam repetidas aos pacientes -, para que os familiares pudessem ter a possibilidade de expressar alguma opinião que não se sentissem confortáveis em que o paciente ouvisse e, posteriormente, possibilitar um outro espaço para uma integração entre eles.

Nas reuniões familiares compareciam apenas um ou, raramente, dois membros da família do paciente participante do curso, porém não de todos os participantes. O familiar que comparecia coincidia com os que participavam mais de perto do tratamento de seu filho, irmão, pai ou mãe. Como não era algo que queríamos impor, pois estávamos buscando uma participação ativa tanto do 
paciente como do familiar, deixávamos em aberto o número de membros familiares participantes, incentivávamos a sua participação e ressaltávamos a sua importância em todo esse processo. Mesmo os que não compareciam, buscávamos deixar isso claro quando os encontrávamos no Caps, passávamos o recado pelo paciente e, eventualmente, nos comunicávamos por telefone.

Nessas reuniões familiares, também coordenadas por mim e pela minha parceira de projeto, aparecia a dificuldade que esses membros tinham com o familiar “doente”, a insegurança em deixá-lo se locomover sozinho, mesmo quando a equipe de profissionais lhes assegurava que o paciente apresentava-se capacitado para tal, de incentivá-lo a retomar atividades abandonadas após o primeiro surto, de dar autonomia nas pequenas atividades cotidianas, de oferecer e dar suporte emocional frente a situações que não lhe eram conhecidas, entre outras.

No decorrer do ano, discutimos sobre a importância de incentivar a autonomia de seu ente em tratamento psiquiátrico. Frisamos que as dificuldades, os anseios, receios, medos e as dúvidas sobre isso poderiam ser conversados ali ou na reunião de parentes que ocorria toda semana, coordenada por um psiquiatra de orientação psicodinâmica. Atentávamos se havia na família o interesse em saber e participar das conquistas e atividades do paciente e os estimulávamos a não esperar apenas que o paciente viesse lhes contar as novidades, possibilitando maior entrosamento na família, uma percepção de interesse pelas habilidades do paciente. Buscou-se nessas reuniões deixar explícito nosso entendimento de que a família é importante na vida do paciente e que estávamos buscando uma parceria, integrá-los nesta atividade proposta e não excluí-los, “deixá-los de lado” ou que o paciente fizesse isso, pois estávamos 
buscando atitudes mais autônomas, independentes e maduras nos pacientes e nas famílias.

No primeiro ano, houve a participação mensal, após autorização do MAM, de uma terapeuta ocupacional da “equipe fixa” do Caps, que também nos supervisionava quinzenalmente, juntamente com a coordenadora do Caps-Unifesp. No segundo ano, não foi possível a participação no MAM da terapeuta ocupacional, além de não haver mais as supervisões, mas sempre conversávamos informalmente com os profissionais do Caps, principalmente a coordenadora, sobre os acontecimentos no MAM.

Para descrever o curso, apresentar-se-á uma contextualização prévia.

O Museu de Arte Moderna (MAM), através do programa "Igual-Diferente” financiado pelo setor privado, oferece à população cursos gratuitos com o objetivo de poder apresentar o “mundo das artes” a pessoas que não têm acesso a ele. Há cursos com temáticas variadas, como escultura, pintura, desenho, reciclagem, fotografia e vídeo. Nos cursos, devido à procura por parte das instituições, a maioria dos alunos eram usuários da área de saúde, mais especificamente, da saúde mental. O MAM e os profissionais participantes deste programa estavam preparados para isso, já que a coordenadora do programa “Igual-Diferente” é uma profissional oriunda desta área.

O curso escolhido foi o intitulado "FOTO e IMAGEM". Nesse curso, tanto no que denominarei de "primeiro ano" (2007) quanto no "segundo ano" (2008), a maioria dos alunos eram do Caps-Unifesp, mesmo havendo uma leve variação na quantidade de pacientes participantes (uma média de 7 pacientes). 
No primeiro ano eram $22^{14}$ participantes do Caps-Unifesp (19 pacientes, 2 psicólogas e 1 terapeuta ocupacional que participava apenas 1 vez por mês) e mais 4 de outras instituições de saúde mental ou da própria população. Nessa “população” está incluso também parentes de pacientes, no caso 1, que quiseram participar.

No segundo ano eram 12 participantes do Caps-Unifesp (10 pacientes e as 2 psicólogas), e outras 10 pessoas oriundas de outras instituições (em sua maioria) ou da população.

Os pacientes do Caps-Unifesp no segundo ano eram pacientes que iriam participar pela primeira vez e pacientes que queriam fazer o curso novamente, embora tenham sido incentivados a participar de um curso "avançado de fotografia”, "Foto e Vídeo”, mas sem a participação das psicólogas. Por esta ausência, os pacientes que participaram do curso de "FOTO e IMAGEM” no ano anterior optaram por repeti-lo.

As aulas eram realizadas em um ateliê espaçoso (anexo 3), no qual havia uma grande mesa, que comportava a todos em suas atividades. Por estarmos dentro do museu, frequentemente as professoras nos levavam para visitar a exposição que estava ocorrendo no momento, sempre com uma explicação teórica sobre o(s) autor(es) das obras e/ou o tipo de arte que estava sendo exposta. Essa visita era utilizada nas aulas do curso posteriormente. Mas se o aluno quisesse em outro momento visitar a exposição (seja porque não foi à aula quando o grupo fez a visita, seja porque queria revê-la), sua entrada e a de mais

\footnotetext{
${ }^{14}$ Mesmo havendo previamente 20 vagas para integrantes do CAPS-HSP, devido ao interesse de mais dois participantes (1 paciente e 1 terapeuta ocupacional), o programa "Igual Diferente" nos cedeu mais duas vagas, permanecendo as outras 4 vagas para integrantes de outras instituições.
} 
um acompanhante era gratuita, por fazer parte do corpo de estudantes do programa "Igual-Diferente".

No início do curso, no primeiro ano, as professoras nos apresentaram seu objetivo, a máquina digital, os recursos que esta apresenta, como manuseá-la (colocar o cordão da máquina no pulso para que a máquina não caia, botão para apertar quando quiser fotografar determinada imagem, etc.) e nos ensinou sobre os recursos, os botões que devem ser apertados quando querem determinado resultado e como usá-los, aos poucos, no decorrer das aulas, usando-os como tema. As aulas eram divididas em parte teórica, prática e, geralmente, visualização e discussão técnica do resultado das fotos tiradas da semana anterior, cujas produções eram projetadas no telão, observadas e discutidas por todos. A discussão era feita pelo "gosto” de cada um, pela questão técnica e pela congruência com o tema da aula. Posteriormente, havia intervenções nas fotos (anexo 4), que eram impressas em papel sulfite, de acordo com a proposta da aula seguinte.

Os recursos apresentados, assim como onde encontrá-los na máquina, foram: “A florzinha”, para tirar fotos de objetos próximos (anexo 5); o modo manual e abertura e velocidade (anexo 6), quando foram tiradas fotos de "Luzes” produzidas por lanternas e folhas coloridas numa sala escura (anexo 7); a mudança de colorido para sépia (anexo 8) ou preto e branco (anexo 9), para dar um efeito mais envelhecido ou de época, respectivamente; como apagar as fotos que não tiveram o efeito desejado; como fazer filmes (mesmo não tendo uma aula em que usasse este recurso, devido à proposta do curso); o timer, para tirar fotos nas quais o fotógrafo também participa da imagem captada; as variações de flash, suas utilidades e efeitos desejados; que botão utilizar para ver a foto tirada 
na máquina. Esses recursos também foram entregues numa explicação escrita sobre onde geralmente se localizam numa máquina digital, o que cada símbolo ou desenho representa e suas funções e o aluno podia levar para casa as fotos.

No decorrer das aulas, a "função automático" era o que ficava mais ativa na máquina, podendo o aluno modificá-la caso quisesse. Alguns alunos preferiam a máquina “pronta” para tirar suas fotos, seja no “automático”, seja em alguma função exercitada em determinada aula, a ter que procurar ou aprender como fazer, apresentando-se de maneira mais passiva, ao passo que outros já “tomavam conta” da máquina, exploravam outros recursos além dos ensinados, sendo pedido para que dessem a chance para que outros também fizessem suas produções fotográficas. Apenas a função “apagar” não era estimulada a ser usada, pois as professoras achavam importante ter registradas todas as fotos tiradas, até mesmo aquelas que o “fotógrafo” não tinha gostado, para discussão, e, com algumas surpresas, aquela foto que seria apagada tecnicamente tinha qualidade.

Havia 5 máquinas fotográficas digitais disponíveis. Na aula prática, os alunos eram divididos em grupos. Cada grupo ficava com uma máquina e a revezava com os demais integrantes. No entanto, alguns pacientes (T., C., S., E.J., A.A., E. e E.K.) queriam estar com a máquina o tempo todo, experimentá-la. Lidar com isso era difícil, pois eram muito criativos e tinham ótimas produções. Porém, tomavam posse da máquina, não deixando muito tempo para os outros exercer a atividade proposta.

No primeiro ano o curso foi ministrado por uma artista plástica que trabalhava com fotos e vídeos, outra que trabalhava com gravuras e uma fotógrafa. Estas duas últimas revezavam entre si suas participações no curso, de 
acordo com a temática e de acordo com seus compromissos profissionais. A primeira permaneceu fixa em todas as aulas, sendo as aulas sempre ministradas em dupla. As ausências ou presenças eram sempre informadas e justificadas aos alunos. Quando a ausência de uma delas era devido a exposições de seu trabalho no exterior, o que geralmente era a razão de suas ausências, os alunos perguntavam, ao retornarem, como tinha sido, o que havia achado da experiência, como era o lugar em que foi. E isso se tornava uma conversa informal antes da aula iniciar. As perguntas eram respondidas de maneira livre e descontraída.

No segundo ano não houve uma divisão tão clara entre as profissionais que se revezavam. A artista plástica que trabalhava com gravuras ficou mais presente, trabalhando juntamente com a artista plástica mais assídua. Se a primeira precisasse se ausentar devido às exposições que fazia, a fotógrafa a substituía e, por uma vez, uma outra profissional, uma artista plástica e professora de outro curso no MAM, compareceu para ministrar a aula.

No segundo ano do curso "FOTO e IMAGEM" (2008), pela maioria dos alunos ainda serem os mesmos, as professoras optaram por modificar a programação das aulas, inovando-as, e reforçando os ensinamentos obtidos no ano anterior. Talvez pela característica do grupo permanecer em sua maioria sem iniciantes, o primeiro ano foi mais técnico e o segundo, mais temático e prático. Na primeira aula, em 2007, houve a explicação da origem da fotografia, o ano, a época, as técnicas utilizadas e a apresentação da máquina digital; em 2008, essas informações foram passadas de forma mais rápida, sendo complementada com um exercício no qual colocamos líquido fotográfico em folha sulfite, algum 
objeto em cima (como folhas e flores) e deixávamos ao sol, resultando na “revelação da imagem”.

Outro tipo de trabalho “mais avançado" realizado no segundo ano foi o Stop Motion, no qual os alunos foram divididos em 2 grupos e cada qual, após uma discussão, decidiu criar história em forma de filme, que teriam que contar, pensando na sequência das cenas, na música e como iriam montar o cenário a partir dos materiais artísticos disponíveis. Após a montagem dos bonecos e dos cenários, foram tiradas fotos sequenciais. Para isso, foi necessário quase um mês de aula. A fotógrafa ficou responsável pela montagem e digitalização das cenas com a música a partir das explicações dadas pelos grupos, pois não havia tempo e computadores que pudéssemos utilizar para fazer isso. Quando finalizado, foi apresentado para todo o grupo. A surpresa com o resultado obtido, do filme realizado com toda sua execução plástica, fotográfica, musical, foi geral, sendo necessária, inclusive, a apresentação dos filmes no Caps para os outros pacientes e profissionais, tamanha a repercussão no local de tratamento.

Outra temática que considerei importante no segundo ano foi a de “Autorretrato" (anexo 10), sendo utilizada em diversas aulas sequenciais. Na primeira aula, foi explicitado teoricamente o tema, os artistas que são reconhecidos por este tipo de trabalho e foi tirada uma foto só do rosto do aluno. Foram impressas duas cópias que, posteriormente, passaram por intervenções artísticas por parte do próprio aluno. Esse trabalho também serviria como a “capa” da nossa pasta. Seria assim a identificação de cada pasta e não pelo nome, como no ano anterior. As aulas seguintes foram nesta temática, mas sem o aluno se colocar na foto e, sim, pensar nas coisas, nos objetos, nas partes do corpo que o identificam. Isso 
possibilitou que cada aluno pensasse em si e em que o individualizava, como o par de sapatos que sempre usava, os óculos, o anel, o penteado, os olhos etc.

Um pequeno exemplo da repercussão desta aula ocorreu com um paciente, AD. Ele descrevia sua imagem, achava-se sempre deformado, com olheiras, olhava-se no espelho o tempo todo no Caps, seu sonho era ser modelo e só usava roupas de grife. Nessa aula, ele não queria tirar a foto. Ele não gostava, pois relatava que a imagem que via não era real, que partes do seu rosto estavam deformadas e isso seria registrado. Após uma conversa com uma das professoras, que foi cuidadosa ao persuadi-lo, dizendo que, caso ele não gostasse, eles apagariam a foto, $\mathrm{AD}$ aceitou tirá-la e escolheu a que achou que ficou melhor. Por um tempo ficou olhando para a foto no visor da máquina, após a professora tirá-la. Na aula seguinte, conseguiu intervir ao redor da imagem na folha impressa e ter uma relação com a imagem que tanto temia. Além disso, seu discurso de que estava com o rosto deformado não era mais frequente, usava mais um estou com uma olheira hoje.

Todos os trabalhos realizados eram guardados em pastas individuais identificadas, sendo entregues ao final de cada ano ao respectivo aluno.

As professoras, no decorrer de todo o curso, mostravam-se afetuosas para com os alunos, tratando-os como tais, independentemente de serem pacientes psiquiátricos, profissionais das instituições, familiares ou qualquer outra coisa. Também se mostravam atentas perante as necessidades que individualmente algum aluno pudesse apresentar, não só no tocante a questões técnicas da fotografia, mas também quando alguém faltava muito por estar internado devido a um surto, ou agindo com firmeza quando alguém violava alguma regra, como estar em um lugar não permitido no momento. Havia a preocupação de usar a 
abordagem correta, e sempre perguntavam para as psicólogas participantes do curso se tinham agido certo com determinada pessoa depois do ocorrido.

Numa destas situações mais difíceis, no primeiro ano, um paciente do Caps-HSP, S., foi até o local onde haveria o desfile do São Paulo Fashion Week (SPFW) de 2007 e se deitou em um dos acentos da plateia enquanto os operários estavam montando a passarela. Um dos seguranças pediu para que ele se retirasse, pois não podia permanecer ali pois estavam trabalhando. Uma das professoras foi chamada. Quando a professora chegou, S. ficou bravo em resposta ao pedido para que se retirasse. Saiu para tomar um ar e desapareceu. Ficamos bastante aflitas, pois ele estava sob nossa responsabilidade, não sabíamos onde ele estava. Saímos à procura pelo prédio do MAM e pelo parque. A professora veio nos perguntar se ela havia feito algo de errado, estava se sentindo culpada, dizendo que foi apenas falar com ele e que ele saiu, sem a ouvir. Diante dessa situação, eu e a outra psicóloga nos dividimos: ela foi procurá-lo pelo parque do Ibirapuera, juntamente com os outros pacientes que também estavam preocupados, e eu fui ao Caps para ver se ele havia retornado para lá, pois não estávamos conseguindo contato telefônico com o serviço. Minutos depois ele chegou ao Caps como se nada tivesse acontecido. Fui conversar com ele e ele ficou bravo e, pela primeira vez, senti medo de ser agredida, pois ele jogou sua mochila no sofá ao meu lado, passando a centímetros de mim e dizendo que uma "menininha" não iria dizer a ele o que fazer ou não fazer e que eu não sabia pelo que ele estava passando. Assim como com a professora, ele não me deixou falar e saiu do Caps. 
O local onde era realizado o SPFW era um espaço no interior do MAM, onde havia as exposições de artistas abertas ao público e onde passávamos para poder chegar até o atelier onde realizávamos as aulas do curso.

Com o passar do tempo, fomos observando que os pacientes davam “desculpas” para não ir (chuva, sono, frio) ou falavam que não iriam. Chamo de “desculpas”, pois, após incentivo e denúncia de que aquilo era uma desculpa, geralmente os pacientes davam uma risadinha, cediam, iam ao MAM e lá aproveitavam a experiência.

Esta situação costumava ser difícil para mim e para minha parceira, pois toda semana, antes de irmos ao MAM, tínhamos a sensação de ter que “emprestar nossa vontade” para os pacientes para que conseguissem fazer o trajeto e comparecer ao curso. Percebíamos que, embora 2 pacientes não quisessem ir porque não estavam gostando do curso, e respeitávamos isso, os outros que davam as ditas “desculpas” pareciam gostar de estar fazendo o curso, falavam sobre ele no Caps com outros pacientes.

Nós os estimulávamos a terem atitude mais ativa e nova. Sabíamos e sentíamos que a nossa presença no curso e no percurso era de extrema importância para estes pacientes. Dava-me a sensação de que, para que eles comparecessem, nós tínhamos que "puxar a corda na qual eles estavam amarrados” para que pudessem sair do lugar. Este empréstimo da nossa vontade sugava nossas energias, deixando-nos cansadas, exauridas, quase sem forças para conseguir chegar até o final do dia. Esta experiência, embora muito desagradável e cansativa, nos auxiliou a compreender um pouco mais como talvez estes pacientes se sentiam quando lhes era dada uma posição mais independente, ativa. 
Com o tempo, fomos percebendo algumas mudanças nesses pacientes e alguns comportamentos que até então não eram possíveis ou não eram vistos no período em que estavam no Caps, ou que fossem verbalizados para a equipe de saúde do Caps, fosse pelos próprios pacientes ou pelos familiares.

Havia um paciente, D., que durante o percurso de ida ao MAM, no decorrer do primeiro ano, andava rápido e sempre ia à frente dos demais. Quando descíamos do ônibus continuava andando rápido, chegando antes no prédio onde tínhamos as aulas, mas sempre nos esperando para entrar no ateliê. Brincávamos com ele, dizendo que estávamos fora de forma, que não conseguíamos acompanhá-lo, que nossas pernas eram mais curtas que as dele. No caminho, tínhamos que passar por uma passarela após descermos do ônibus. Um dia, no final do primeiro ano do curso, D. conseguiu nos comunicar algo: tenho a impressão que esta ponte vai cair. Tenho medo de passar nela. Foi-lhe dito: como você é corajoso. Mesmo com medo, você passa por ela toda semana. Essa passarela passa por cima da Avenida 23 de Maio, muito movimentada. D. nos deu um sorriso como se tivesse tirado um peso imenso de suas costas. Esse paciente continuou no curso por todo o ano e optou fazê-lo novamente no ano seguinte, já que sabíamos que haveria algumas modificações das técnicas ensinadas. E por todo esse tempo continuou passando pela "ponte” no caminho de ida, mas nos acompanhando mais nos nossos curtos passos.

Este mesmo paciente nos mostrou outras mudanças comportamentais importantes. Principalmente depois de seu primeiro surto psicótico, a relação com seu pai era bastante distanciada. Vale ressaltar que D. tem pai oriental e mãe brasileira, o que, a meu ver, pode nos dizer um pouco mais sobre uma relação pai-filho, como rigidez no contato, dificuldade em expor sentimentos. Sua mãe 
era superprotetora, chegando a ser invasiva. Esta mãe também foi cuidada, orientada pela equipe do Caps e se submetia à psicoterapia. Ao final do curso, assim como os demais alunos, D. recebeu uma pasta com todas as suas produções fotográficas impressas em papel sulfite e as produções artísticas que realizou. D., durante jantar em sua casa, mostrou essa pasta ao pai, que elogiou seu trabalho e conversaram sobre o assunto. Isso nos foi relatado pela mãe, que sempre comparecia aos grupos com os familiares. Além disso, sua mãe também relatou uma mudança não só de proximidade com o pai, como de maior sociabilidade de modo geral (D. apresentava-se bastante retraído), e que ensinou à irmã (que só sabia apertar o botão de tirar fotos) as funções de sua máquina digital que acabara de comprar.

Outra paciente, C., que já se encontrava em tratamento ambulatorial, fazia tratamento psicoterápico particular há muitos anos, tinha o acompanhamento constante de seu psiquiatra e realizava um grupo semanal de "relaxamento" no Caps para os outros pacientes (propôs esse grupo ao Caps após uma experiência sua), queixava-se bastante que se sentia sozinha, que não se sentia à vontade em falar de si e seus sentimentos nem mesmo para sua psicoterapeuta ou seu psiquiatra, pois tinha medo de ser julgada.

No percurso para o MAM, C. sempre ficava ao meu lado e me procurava para conversas, pois dizia que se sentia compreendida por mim e que eu a fazia pensar. Essa paciente já teve uma experiência profissional de tirar fotos 3X4, gostava de trabalhos artesanais e achava que seria importante ter mais uma atividade naquele momento de sua vida, e que por isso se inscrevera no curso do MAM. C. já tinha um bom vínculo comigo quando fui estagiária, mas nada que me chamasse muito a atenção. Aos poucos, ao ir com os pacientes até o MAM, 
C. foi se aproximando e conversando. Com o tempo, começou a me relatar coisas de sua vida, de suas emoções, o fato de não conseguir se abrir com ninguém, de seus sentimentos de culpa, de seu vício por cartões de crédito, de lojas, de suas dívidas financeiras etc. Nós percebíamos que C. estava conseguindo estar mais próxima a mim (os profissionais do Caps que cuidam direta ou indiretamente de C. diziam que ela não tinha tido até então este tipo de proximidade) e achamos que poderíamos usar disso para C. compreender algumas questões suas, as suas constantes internações, mas tomando cuidado para que não se tornasse dependente a mim, buscando auxiliá-la em sua autonomia. Ela dizia que se eu não fosse ao MAM, ela também não iria, e tivemos a oportunidade de conversarmos sobre a importância da busca de sua autonomia e da possibilidade de ir para o curso por ela própria. C. frequentemente era internada, principalmente quando chegava o final do semestre ou do ano.

Essa paciente também se inscreveu no curso em 2008, pois no ano anterior tinha perdido muitas aulas devido às suas internações psiquiátricas. Durante os dois anos que participou das oficinas, teve algumas crises e foi internada, mas pareceu sempre levar consigo o curso. Sempre perguntava como havia sido a aula que perdeu, se as professoras falavam dela, se as fotos ficaram boas. No terceiro ano ${ }^{15}$, devido a uma forte crise e longo período de internação, não conseguiu realizar o primeiro semestre satisfatoriamente e, após minha saída do Caps e do curso do MAM, ela não deu continuidade ao curso.

Outro paciente, F., que teve seu primeiro surto psicótico na segunda década de vida, quando já tinha uma formação universitária, trabalhava (funcionário público), abrindo mão de tudo isso por se sentir perseguido (este era um de seus

\footnotetext{
${ }^{15}$ Este "terceiro ano" indica que o projeto teve sequência posteriormente.
} 
sintomas) e por estar mais distanciado afetivamente, confuso, com medo. Este paciente já estava em tratamento há alguns anos no Caps e se mostrava bastante reservado. Permanecia por muito tempo sem atividade alguma fora de sua casa, exceto suas aparições no tratamento. Seus trabalhos apresentados no curso tinham muito cunho político, a descrição quase que literal de seu estado emocional (por exemplo: foi fotografado dentro de um rolo grande de papel que havia na sala de aula e, na verificação dos resultados projetados no telão, justifica que estava bastante enrolado naquele momento de sua vida - anexo 11), e eram bastante criativos. No segundo semestre do primeiro ano, F. decidiu fazer cursinho, pois queria prestar vestibular para Ciências Sociais no final do ano, mas não passou na prova para nenhuma universidade. No entanto, pareceu não se cobrar muito, relatando a sua compreensão do tempo longo que estava sem estudar e que universidade pública era mais concorrida. Manteve seus estudos no cursinho no decorrer do ano seguinte, conseguindo uma vaga no curso que escolheu, na USP, e está conseguindo cursar a faculdade até o momento. Além disso, colocava-se de modo ativo no Caps, sugerindo discussões na época das eleições, apoiando e colaborando com novos projetos propostos pela equipe.

As vivências ocorridas no MAM e com os pacientes neste ambiente novo e no percurso como um todo também eram levadas às reuniões clínicas semanais no Caps, quando se discutia sobre determinado paciente. Nestas reuniões estavam todos dos funcionários que trabalhavam no Caps, inclusive estagiários, residentes, assistentes de enfermagem. Acredito que tenha sido importante esta visão diferenciada, pois enriquecia a discussão e compreensão do caso, assim como a discussão de projeto terapêutico futuro para o paciente em questão. 
No início do segundo semestre de 2009 realizou-se uma seleção de fotos tiradas no curso “FOTO e IMAGEM” nos anos de 2007 e 2008, reveladas e colocadas em quadrinhos para exposição no próprio espaço físico do Caps-HSP. A seleção das fotos foi feita conjuntamente com seus autores, que continuavam seu tratamento no Caps, e a montagem dos quadrinhos, por eles próprios e por outros que se encontravam lá e que tiveram curiosidade e interesse em ajudar. A seleção teve como critérios a estética da foto, técnica utilizada e a necessidade de haver pelo menos uma produção de cada paciente que participou. Essas fotos hoje estão expostas pelo Caps juntamente com outros trabalhos artísticos, para apreciação dos profissionais, funcionários, colegas, familiares e por eles próprios.

As potencialidades das professoras também eram destacadas nas aulas. Como visto, no curso de fotografia havia uma fotógrafa. Mas, além disso, outras possibilidades artísticas que tinham uma correspondência com imagem eram ensinadas. Uma das professoras tinha como especialidade a gravura feita a partir de chapas de cobre. Após a explicação técnica de como seu trabalho era realizado, foi-nos oferecida a oportunidade de confecção de uma gravura a partir de uma placa de madeira (xilogravura), sendo-nos então apresentadas as ferramentas, o modo seguro de uso, a possibilidade de imprimir texturas, entre outros aspectos artísticos. Estando a matriz (placa de madeira) pronta após a intervenção, era passada uma tinta apropriada para a xilogravura e impressa em papel sulfite. Com isso, a imagem gravada se revelava e, se necessário, eram feitas correções na matriz.

Esse curso foi apresentado tanto no primeiro, quanto no segundo ano. No primeiro ano, esta aula foi mixada com as aulas de "Sequência" (anexo 12), onde 
as fotos tiradas tinham o tema de seqüência. Com isso, havia intervenções posteriores na madeira, após as primeiras impressões da primeira imagem feita na matriz, apresentando, no final, três a quatro imagens que eram sequenciais. Já no segundo ano houve um aprofundamento do uso da técnica para aqueles que já haviam realizado a xilografia no ano anterior e a apresentação desta para os iniciantes, mas sem a temática de sequência.

No mesmo caminho de enfatizar as potencialidades de cada um, e retomando uma preocupação que tínhamos no início do projeto, a autonomia do paciente, no final do $1^{\circ}$ semestre do $1^{\circ}$ ano já íamos encorajando os pacientes para nos encontrarmos no MAM e/ou voltar direto para casa, sem precisar da companhia das psicólogas. Alguns pacientes conseguiram (em torno de 8), no decorrer do ano, mas ainda precisavam ir junto conosco, saindo do Caps-HSP. Parecia que era mais fácil voltar sozinhos do que ir. Porém, juntamente com algumas modificações terapêuticas (pois no dia que íamos ao MAM não era o dia de determinado paciente ir ao Caps-HSP), e continuando o incentivo no ano seguinte, alguns dos pacientes já conseguiam nos encontrar no MAM e voltar sozinhos para casa. Porém, isso não ocorreu no início do ano. Ocorreu no final do primeiro semestre de 2008. Após as férias, ao menos na primeira aula, queriam ir com as psicólogas, mas logo retomávamos e incentivávamos a autonomia na locomoção que estavam conquistando, realizando a locomoção por si próprios.

No segundo ano não tivemos o transporte da instituição, como houve no início do primeiro ano. Já íamos e voltávamos de transporte público.

Na última aula de cada semestre de cada ano havia uma confraternização no ateliê em que tínhamos aula, na qual os comes e bebes eram divididos por 
todos. Havia uma conversa e decisão de quem levaria o prato e a bebida. Isso era sempre muito esperado pelos pacientes, mas alguns nem sempre compareciam no último dia. E, como observado até mesmo no próprio Caps-Unifesp, tais pacientes eram os que geralmente tinham grandes dificuldades em lidar com despedidas e términos em geral. 


\section{DISCUSSÃO}

O trabalho apresentado demonstra mudanças positivas em pacientes que realizavam tratamento no Caps-HSP e participaram do curso "FOTO e IMAGEM” no MAM, como maior autonomia, melhor relacionamento interpessoal, possibilidade de retomar ou iniciar um projeto de vida, possibilidade de se vincular em algum espaço que não o de tratamento e, acima de tudo, de reconhecimento de potencialidades antes esquecidas ou desconhecidas.

Estar no Caps, por melhor que seja, também os exclui de alguma maneira da sociedade. O trabalho propôs um acompanhamento externo à instituição com o intermédio da arte.

Este tipo de cuidado, juntamente com o tratamento no Caps, possibilitou ao paciente se colocar como sujeito, como alguém capaz e também responsável, e não apenas como alguém que só recebe (cuidado, tratamento, compreensão, tolerância) de maneira passiva, como espectador da própria vida; sobretudo quando estava presente o apoio familiar, um olhar do outro “primário” e também das terapeutas.

A aproximação das potencialidades de cada um dos participantes do curso foi possível a partir do (re)conhecimento de seu idioma pessoal (SAFRA, 2006) e do sentido de sua existência (BELLO, 2006), a partir das produções fotográficas e artísticas realizadas. Ou seja, pode-se aproximar do outro em suas potencialidades e recursos e também em seus prejuízos decorrentes da falta da vivência de experiências humanas significativas no cotidiano. 
O mundo contemporâneo tem sido marcado pelo imediato, pelo automatismo, pela técnica, e não pela experiência, não pelo sentimento (SAFRA, 2004, 2005, 2006). Diante dessa realidade o espírito humano se fragmenta. Esta perspectiva de trabalho terapêutico trata de um reposicionamento da clínica psicológica como elemento ético-ontológico que possibilita à dupla profissional-paciente se sentir enraizada na experiência humana. O profissional acolhe o vivido, o vivo e principalmente o anseio pelo devir ou seu impedimento, o Real e o mistério da existência humana.

Do ponto de vista fenomenológico, o terapeuta não se guia pelos sintomas, nem mesmo deseja que desapareçam, mas auxilia o paciente a encontrar um sentido para essas vivências, desde que se estabeleça um vínculo de confiança significativo. As vivências psicopatológicas têm para cada paciente um significado, mesmo que seus comportamentos sejam universalmente parecidos. $\mathrm{O}$ que interessa nesta vertente é como cada indivíduo vive a doença e/ou sofrimento que os afeta. Por vezes, esses sintomas, são sinais de alerta para que se possa iniciar uma relação humana, uma verdadeira interlocução baseada em uma relação ética que vise compreensão e reconhecimento, uma comunicação e convivência humana almejadas.

Os pacientes que apresentam alguma psicopatologia ou intenso sofrimento emocional têm dificuldades em encontrar sentido para suas vivências. O ser humano que vive essas experiências com frequência busca alguém para ajudá-lo a enfrentar tais vivências que o assaltam por dentro, mesmo que justifique como vindo de fora. Muitas pessoas apresentam um estreitamento da vivência passível de encontrar significado na existência, um aprisionamento em experiências que ainda não encontraram um sentido humano. Não há a 
possibilidade de abertura, mas um aprisionamento em si mesmo. Não uma expectativa de devir, mas um congelamento, um bloqueio, uma barreira. Todo ser humano tenta elaborar as diversas situações e etapas da vida na presença de outrem, da sua comunidade e da sociedade na qual está inserido. Não acessar a dimensão espiritual da estrutura da personalidade humana (BELLO, 2004) leva o ser humano a impedimentos que estancam o uso da liberdade e do livre arbítrio.

Em suma, este trabalho visou unir aspectos da teoria fenomenológica (BELLO, 2004, 2006) com uma prática clínica (WINNICOTT, 1975; SAFRA, 2006) que vislumbrou a possibilidade do ser humano em sair de um círculo vicioso, angustiante, patológico, para uma vivência de possibilidades e potencialidades, indo em direção ao uma espiral tridimensional e não a um achatamento de si.

Mesmo tendo em vista um escasso número de trabalhos publicados com a temática arte-Caps-tratamento, é possível observar a utilização e a importância do contato com a arte para o desenvolvimento pessoal de pessoas em tratamento para doenças mentais em centros especializados. Isso demonstra a necessidade iminente de mais pesquisas na área.

Quando vimos um paciente deitado, fumando, passivo, intuímos que algo deveria ser feito por aquelas pessoas e a partir daí teve-se a ideia do projeto. 


\section{CONCLUSÃO}

Um dos elementos importantes da relação com a arte é de que não há uma relação de cura com ela como há na relação médico-paciente. Quando alguém vai em busca de um médico, na vasta maioria das vezes pressupõe-se que haja uma expectativa de cura, de melhora. Já com a arte, há uma certa gratuidade, um deleite, algo que ainda está por vir e que não se sabe o quê. A arte permite ao indivíduo expressar-se, sem haver cobranças e expectativas.

A arte-educação, como em um curso teórico-prático de uma técnica artística, estimularia a abertura expressiva, levando-se em conta o material e a continência do mesmo. Nas aulas havia sempre uma delimitação, um material a ser utilizado, uma técnica, um objetivo, o que ajudava esta experiência ser uma experiência de autodescoberta e não de terror. Isso implica a expressividade de si mesmo pelo objeto e uma afirmação do valor pelo artístico.

A arte também é vista como um meio de comunicação entre os indivíduos, entre si mesmo, até entre os povos, mas, além disso, ela pode ser um meio de comunicação de um desenvolvimento interno, pessoal, de crescimento enquanto pessoa, ser humano. Por meio dela, pode haver o encontro consigo mesmo.

Através da arte, pode-se auxiliar o indivíduo a constituir seu self; e pode-se ter uma área intermediária, na qual ele possa lidar com a tensão ao relacionar a realidade interna à externa. Na experiência demonstrada no Diário de Campo, alguns desses exemplos se dão quando, durante o período em que faz o curso, o paciente passa a buscar uma profissão com a qual se identifica, retoma seus estudos e ingressa em uma universidade; e quando não quer tirar a foto de seu rosto na aula de “Autorretrato”, dizendo que a imagem que via não era real. 
Este desenvolvimento pôde ser auxiliado pela arte, pois ela pode ser uma via de simbolização, na qual e pela qual o indivíduo pode expressar a sua criatividade e lidar com as suas ilusões inerentes ao ser humano.

Ao tirar as fotos, os pacientes tinham a possibilidade de se experimentar, experienciar suas potencialidades e limitações, utilizando-se da sua imaginação, da ilusão, através da criatividade. Estimulamos assim o relacionamento com o outro e auxiliamos o indivíduo a desenvolver outras maneiras de estar no mundo que não como paciente passivo.

O contato com a arte também se dá a partir do registro corpóreo, ou seja, sensorial, através do símbolo apresentativo, propiciando, em decorrência à sensibilidade, uma experiência vivida, estética, proporcionando um saber não intelectual. O acesso à capacidade de compreender o símbolo apresentativo decorre a partir da elaboração imaginativa do corpo, através da sensorialidade, devido às inter-relações corpóreas com o ambiente. Isso vai de encontro com o conceito de empatia, a qual se dá no registro corpóreo e não mental, por meio da sensibilidade, levando o indivíduo a reconhecer em si mesmo experiências que não foram vividas por ele, mas acompanhada pela experiência de outras pessoas.

Esta experiência também pôde ser vivida devido ao fato de o MAM ter sido um espaço potencial para desenvolver as capacidades criativas individuais, pessoais, que talvez não estivessem podendo ser estimuladas quando o indivíduo era visto por ele, e por outros, enquanto limitado, ausente, passivo, paciente. Mesmo o Caps tendo profissionais que buscam o melhor que o paciente tem a oferecer, ele ainda está lá para receber tratamento, acima de tudo. Em casa, por mais que o amem, ele pode ser visto como o que tem "problemas". No curso no MAM, ele pode ser uma pessoa, que está lá aprendendo. A questão terapêutica 
acaba sendo secundária. Durante o curso e o percurso, os pacientes e as psicólogas estavam na mesma condição humana e isso foi um facilitador para o contato com o outro.

Além da escolha do espaço, houve a forma como o curso foi escolhido e realizado, o cuidado das psicólogas em obter informações anteriormente sobre o curso e as professoras, o cuidado das professoras nas aulas e quando elas se ausentavam devido a algum compromisso profissional. Isso demonstra características de uma mãe suficientemente boa assim como quando estas psicólogas vão aos poucos estimulando a autonomia e a responsabilidade destes pacientes, pois aqui as professoras conseguiram perceber as necessidades destes pacientes e essa percepção foi captada pela sensorialidade; houve o reconhecimento de uma subjetividade e uma intersubjetividade, buscando compreender este paciente e não explicá-lo.

Quando as psicólogas marcaram a primeira reunião com os pacientes para apresentar o curso no MAM, elas os colocavam no lugar de sujeitos, com escolhas, direitos e deveres, em comunidade com o outro.

A família também, parte deste comunitário, foi incluída neste projeto, possibilitando uma abertura para o desenvolvimento, tendo em vista que foi observado, durante o período de estágio, que a família pouco possibilitava a autonomia, seu livre expressar, o crescimento individual de seu parente em tratamento. Através da reflexão houve a possibilidade de uma abertura por parte dos familiares a possibilidades de desenvolvimento de uma alteridade e solidariedade, possibilitando melhor apreensão empática para com seu parente e compreensão da condição deste. 
Através do ato de criar, de comunicar dentro de certas regras (materiais específicos, objetivos da atividade) algo que queira, o indivíduo tem a possibilidade de colocar aspectos de si, de suas escolhas; de expressar facetas de sua história; de lidar com algo que lhe seja próprio; de apresentar seu idioma ou semântica pessoal; de ser reconhecido por ele próprio e pelos outros. Com isso, abre-se a possibilidade de construção de uma descoberta de recursos internos para seguir a constituição do self. Além disso, a experiência da atividade já é saudável, possibilitando uma transcendência para a dimensão da liberdade, levando a um desenvolvimento humano, conseguindo reconhecer a vivência do outro.

O contato com a arte neste estudo foi compreendida como uma experiência que pode ajudar o indivíduo - concebido como ente aberto ao sentido de ser - a resgatar recursos adormecidos em seu self através do acompanhamento cuidadoso e atento das psicólogas, a inclusão da família, no tratamento interdisciplinar em saúde mental.

Mesmo admitindo que a arte, o acompanhamento dos pacientes, juntamente com o tratamento no Caps possivelmente trouxeram modificações na qualidade de vida dos pacientes, apenas uma destas possibilidades trabalhada isoladamente também não poderia trazer resultados semelhantes? Apenas o acompanhamento até o local do curso não pareceu ser suficiente para alguns dos pacientes do CapsUnifesp conseguirem se manter no curso?

Além disso, neste estudo não houve acompanhamento dos demais alunos do curso que não eram do Caps-Unifesp, portanto não foi possível averiguar possíveis mudanças nestes, a fim de verificar a importância da arte para tais indivíduos. 
Alguns pacientes que apenas realizavam tratamento no Caps-Unifesp também demonstraram alguma melhora sintomatológica, embora tais dados não tenham sido mensurados para tal estudo e comparados com os pacientes participantes do curso. 


\section{REFERÊNCIAS BIBLIOGRÁFICAS}

ANDRADE, P.A.S. A fotografia como instrumento de intervenção clínica junto a pacientes psicóticos. Dissertação de mestrado, Pontifícia Universidade Católica de São Paulo, São Paulo, 2010.

BELLO, A.A. A fenomenologia do ser humano. Tradução de Antônio Angonese. Bauru, São Paulo: EDUSC, 2002.

Fenomenologia e Ciências Humanas: Psicologia, História e Religião. Organização e tradução de Miguel Mahfoud e Marina Massimi. Bauru, SP: EDUSC, 2004.

Introdução à fenomenologia. Tradução de Ir. Jacinta Turolo Garcia e Miguel Mahfoud. Bauru, São Paulo: EDUSC, 2006.

BELMONTE, S.A. Refletindo a Alegria, a Beleza e a Criatividade no Espelho de D.W.Winnicott. In: MOTTA, I.F. Psicanálise no século XXI: As conferências brasileiras de Robert Rodman. Aparecida, SP: Ideias \& Letras, 2006.

CASTRO, E.D. A dança, o trabalho corporal e a apropriação de si mesmo. Rev. Ter. Ocup. 3(1/2):24-32.ilust., 1992.

CHIZZOTTI, A. Pesquisa em Ciências Humanas e Sociais. São Paulo: Cortez, 1988.

DICIONÁRIO Priberan da Língua Portuguesa. São Paulo, 2011. Disponível em: <http://www.priberam.pt/DLPO/>. Acesso em: 09 abr. 2011.

MAMEDE, M.C. Cartas e retratos: uma clínica em direção à ética. Tese de doutorado, Universidade de São Paulo, São Paulo, 2002.

MARTINS, J., \& BICUDO, M.A.V. A pesquisa qualitativa em psicologia: Fundamentos e recursos básicos. São Paulo: Ed. Moraes/Educ., 1990.

MARTINS, M.A., BARREZZI, J.M.P.A., \& FERREIRA, M.C.M.P. A inserção social de portadores de transtornos mentais através da arte. Saúde e Sociedade, v. 18, supl. I., 2009.

MINKOWSKI, E. (2000). La esquizofrenia: Psicopatología de los esquizoides y los esquizofrénicos. México, D. F.: Fondo de Cultura Económica, 2000. p. 79-83. (trabalho original publicado em 1927).

Os Esquizofrênicos pintados por eles mesmos. Cahiers Du Groupe Françoise Minkowska. Eugene Minkowski - Recueil d'articles 1923-1965, n. 15 F., 1965. 
MOREIRA, M.S.G. Função Integrativa do Humor. In XI International Symposium for the Psychotherapy of Schizofrenia, Washington D.C., 1994.

ROSSI, C. (2009). Arte e psicanálise na construção do humano. Revista da Sociedade Brasileira para o Progresso da Ciência. Ciência e Cultura. Art\&Psicanálise, 61(2), 25-27, 2009.

SAFRA, G. A Po-Ética na Clínica Contemporânea. Aparecida, SP: Ideias \& Letras, 2004. (Coleção Psicanálise Século I).

A Face Estética do Self - Teoria e Clínica. Aparecida, SP: Ideias \& Letras: São Paulo: Unimarco Editora, 2005.

Hermenêutica na Situação Clínica: O Desvelar da Singularidade pelo Idioma Pessoal. São Paulo: Sobórnost, 2006a.

Placement: modelo clínico para o acompanhamento terapêutico. Psychê, Ano X (18), 13-20, 2006b.

STEIN, E. La esencia de los actos de empatia. In Sobre el problema de la empatia. Parte II do tratado apresentado com o título El problema de la empatia en su desarrollo histórico y en consideración fenomenológica. Halle: Imprenta de la Waisenhaus. (Trabalho original publicado em 1917), 2004a.

La empatia como comprensión de personas espirituales. In Sobre el problema de la empatia. Parte IV do tratado apresentado com o título El problema de la empatia en su desarrollo histórico y en consideración fenomenológica. Halle: Imprenta de la Waisenhaus. (Trabalho original publicado em 1917), 2004b.

La estructura de la personalidad humana. $1^{\mathrm{a}}$ ed. Tradução de J. Mardomingo. Madrid: Estudios y ensayos. BAC. Filosofía y Ciencias. (Trabalho original publicado em 2004), 2007.

TAVARES, C.M.M. O papel da arte nos centros de atenção psicossocialCaps. Rev. Bras. Enf., 56 (1): 35-39, jan-fev., 2003.

TOURAINE, A. Crítica da Modernidade. Petrópolis: Vozes, 1999.

TURATO, E.R. Tratado de metodologia de pesquisa clínico-qualitativa. Petrópolis: Vozes, 2003.

WIKIPÉDIA. São Paulo, 2011. Disponível em: $<$ http://pt.wikipedia.org/wiki/Hermen\%C3\%AAutica>. Acesso em: 02 maio 2012.

WINNICOTT, D.W. O brincar e a realidade. Tradução de José Octávio de Aguiar Abreu e Vanede Nobre. Rio de Janeiro: Imago Editora. (Trabalho original publicado em 1971), 1975. 
O ambiente e os processos de maturação. Estudos sobre a teoria do desenvolvimento emocional. Tradução de Irineo Constantino Schuch Ortiz. Porto Alegre: Artmed. Reimpressão 2008. (Trabalho original publicado em 1979), 1983.

Da Pediatria à Psicanálise - obras escolhidas. Tradução de Davy Bogomoletz. Rio de Janeiro: Ed. Imago. (Trabalho original publicado em 1958), 2000.

Privação e delinquência. Tradução de Álvaro Cabral, revisão de Monica Stahel. São Paulo: Martins Fontes. (Trabalho original publicado em 1984), 2005. 


\title{
ANEXOS
}

ANEXO 1

\section{Termo de Consentimento Livre e Esclarecido}

\author{
A Arte como Intermediador Terapêutico.
}

Essas informações estão sendo fornecidas para sua participação voluntária neste estudo, que visa pesquisar um manejo terapêutico através do ensino de técnicas das artes plásticas por profissionais da área. Serão recolhidas informações das observações in loco realizadas durante as atividades desenvolvidas no complexo do Museu de Arte Moderna de São Paulo, assim como acompanhamento no local de tratamento. Não há benefício direto para o participante. Trata-se de estudo experimental testando a hipótese de que por meio da arte pode haver uma melhora na qualidade de vida de pacientes psiquiátricos.

Em qualquer etapa do estudo, você terá acesso aos profissionais responsáveis pela pesquisa para esclarecimento de eventuais dúvidas. O principal investigador é a Psicóloga Sheila de Marchi que pode ser encontrado no endereço Av. Prof. Mello Moraes, 1.721 - Cidade Universitária - CEP 05508-030 - São Paulo - SP, telefone: (11) 3091-1946. Se você tiver alguma consideração ou dúvida sobre a ética da pesquisa, entre em contato com o Comitê de Ética em Pesquisa com Seres Humanos do Ipusp - Av. Prof. Mello Moraes, 1.721, Bloco G, sala 22, Cidade Universitária, São Paulo, SP, telefone: (11) 3097-0529.

É garantida a liberdade da retirada de consentimento a qualquer momento e deixar de participar do estudo sem qualquer prejuízo à continuidade de seu tratamento na Instituição; As informações obtidas serão analisadas em conjunto com as de outros voluntários, não sendo divulgada a identificação de nenhum paciente; Há o direito de ser mantido atualizado sobre os resultados parciais das pesquisas quando de conhecimento dos pesquisadores.

Fica assegurado o sigilo do participante, mesmo diante da possibilidade de publicação dos resultados da pesquisa. 
Não haverá despesas pessoais para o participante em qualquer fase do estudo, assim como também não há compensação financeira relacionada à sua participação. Em caso de dano pessoal diretamente causado pelos procedimentos ou tratamentos propostos neste estudo (nexo causal comprovado), o participante tem direito a tratamento médico na Instituição, bem como às indenizações legalmente estabelecidas. Compromete-se o pesquisador em utilizar os dados e o material coletado somente para esta pesquisa.

Acredito ter sido suficientemente informado a respeito das informações que li ou que foram lidas para mim, descrevendo o estudo: "A Arte como Intermediador Terapêutico". Eu discuti com a Psicóloga Sheila de Marchi sobre minha decisão em participar desse estudo. Ficaram claros para mim quais são os propósitos do estudo, os procedimentos a serem realizados, seus desconfortos e riscos, as garantias de confidencialidade e de esclarecimentos permanentes. Ficou claro também que minha participação é isenta de despesas e que tenho garantia do acesso a tratamento hospitalar quando necessário. Concordo voluntariamente em participar deste estudo e poderei retirar o meu consentimento a qualquer momento, antes ou durante o mesmo, sem penalidades ou prejuízo ou perda de qualquer benefício que eu possa ter adquirido, ou no meu atendimento neste Serviço.

Assinatura do paciente/representante legal

Data

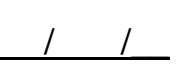

Assinatura da testemunha

Data 11

Para casos de voluntários menores de 18 anos, analfabetos, semianalfabetos ou portadores de deficiência auditiva ou visual. 
Declaro que obtive de forma apropriada e voluntária o Consentimento Livre e Esclarecido deste paciente ou representante legal para a participação neste estudo.

Assinatura do responsável pelo estudo

Data

$1 \quad 1$ 


\section{ANEXO 2}

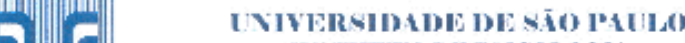

IVSTTETO DE: PAICOIAOFit

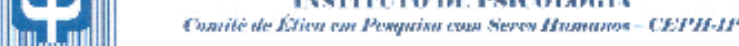

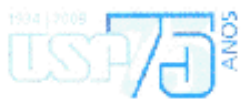

Of.092-CEPH-IP - 26/08/2009

Senhor Professor

O Comitè de Ética em Pesquisa com Seres Humanos do IPUSP $\{\mathrm{CEPH}-$ IP) aprovou, conforme parecer anexo, o Projeto de Pesquisa $n^{12}$ 2009.033 intitulado: 'Arte como intermediador terapeutico", a ser desenvolvido por sua orientanda Sheila de Marchi, nivel Mestrado, do Programa de Pós-Graduaçāo em Psicologia Clínica do IPUSP.

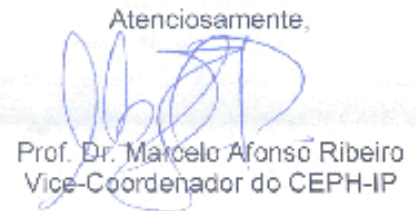

Ilmo. Sr.

Prof. Andrés Eduardo Auirre Antúnez

Programa de Pós-Graduaçäo em Psicologia Clínica do IPUSP

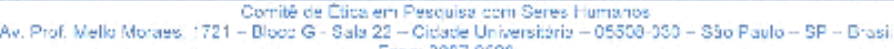
Fere: 2007 0 025 


\section{ANEXO 3}

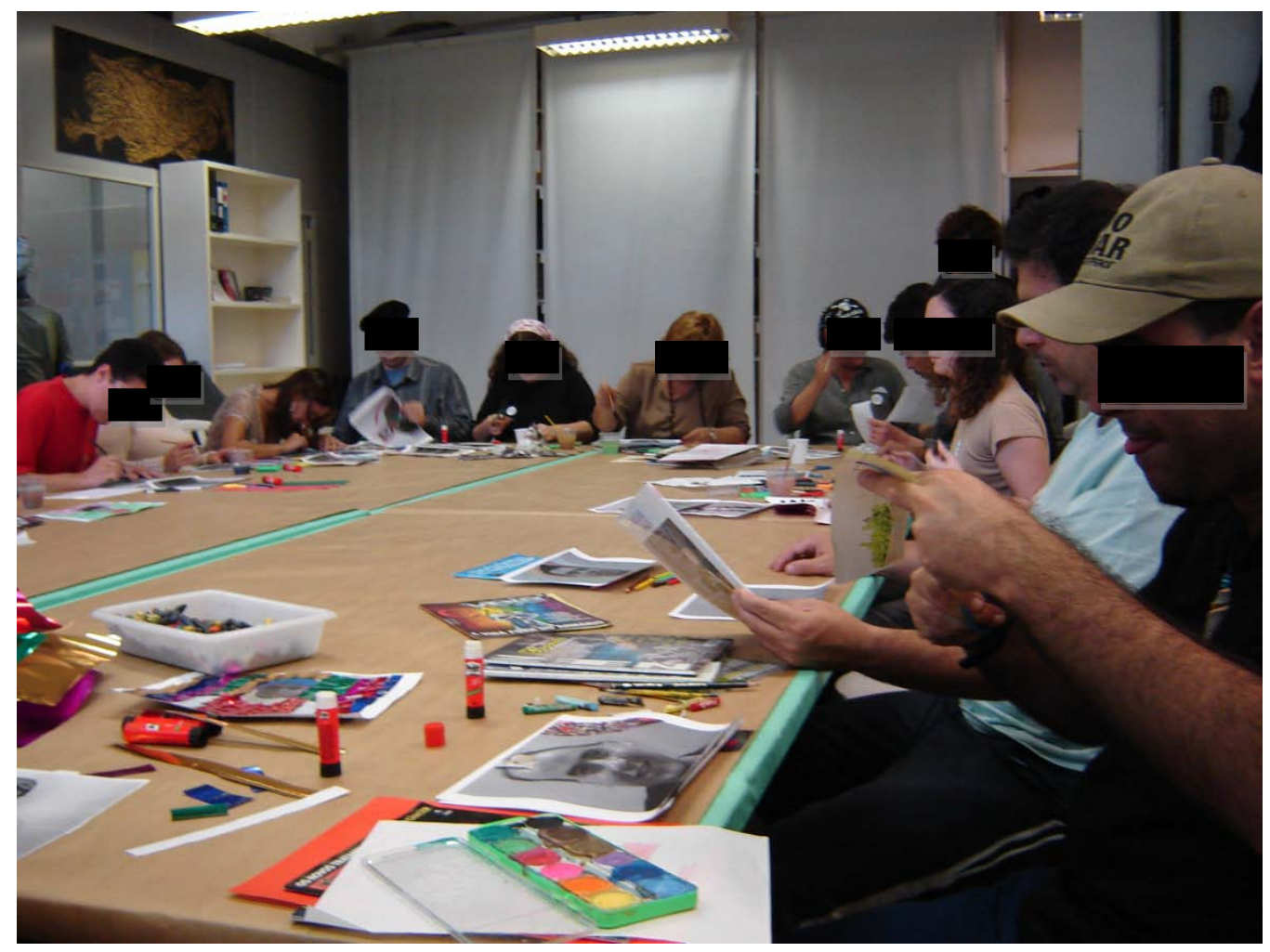

Figura 1 - Ateliê. 
ANEXO 4

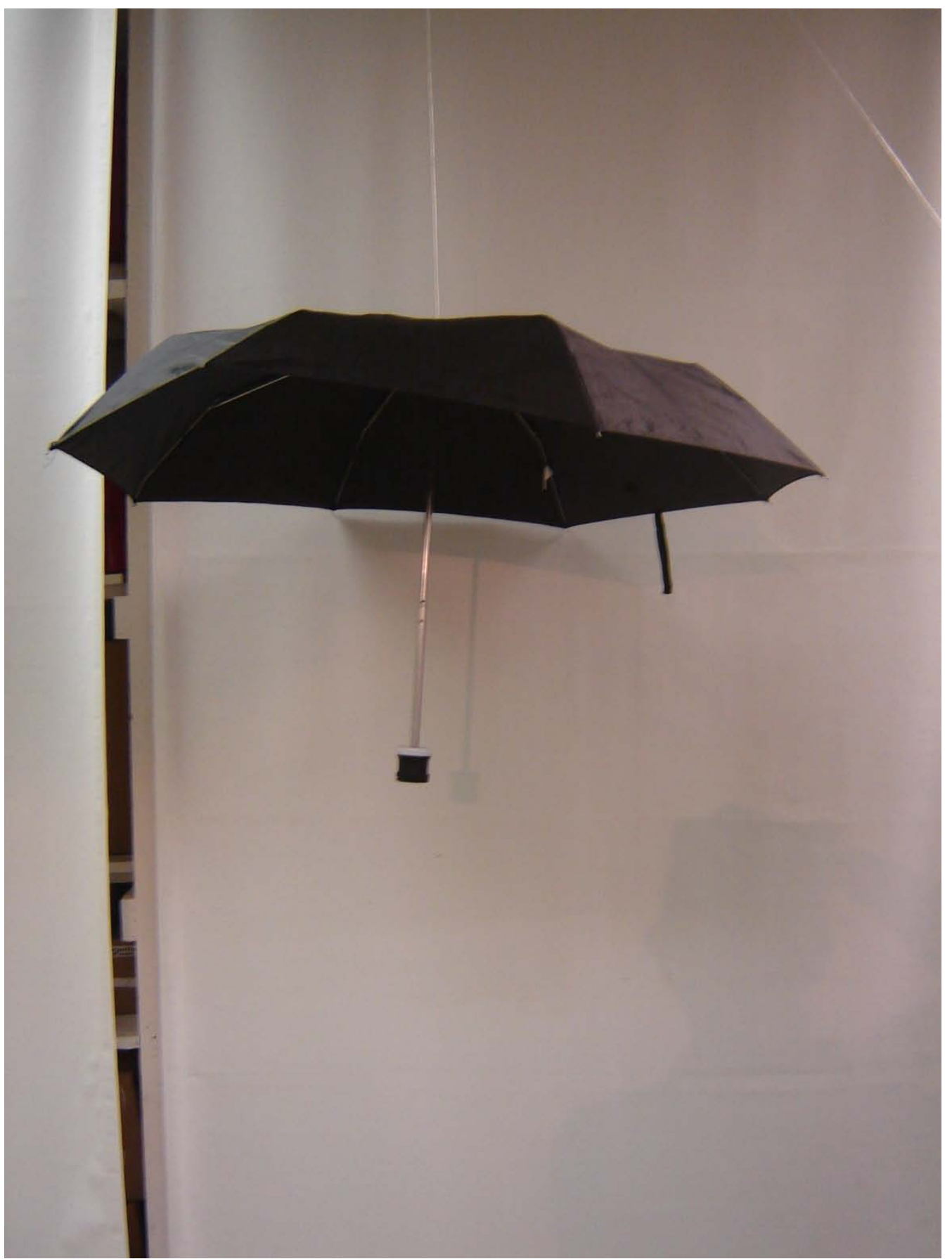

Figura 2 - Fotografia tirada em 05.11.2007. 


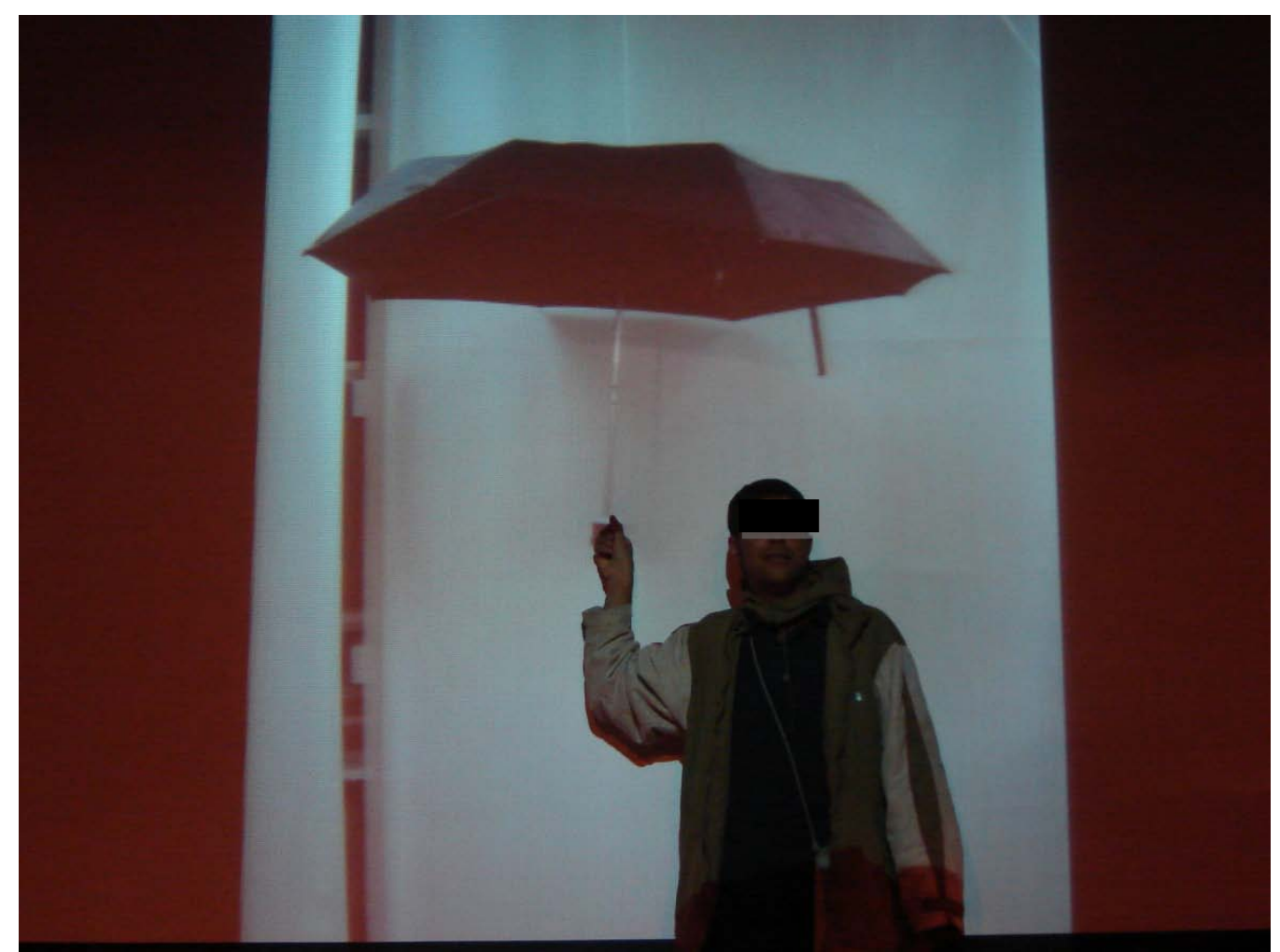

Figura 3 - Fotografia tirada em 12.11.2007. Intervenção na produção do dia 05.11.2007.

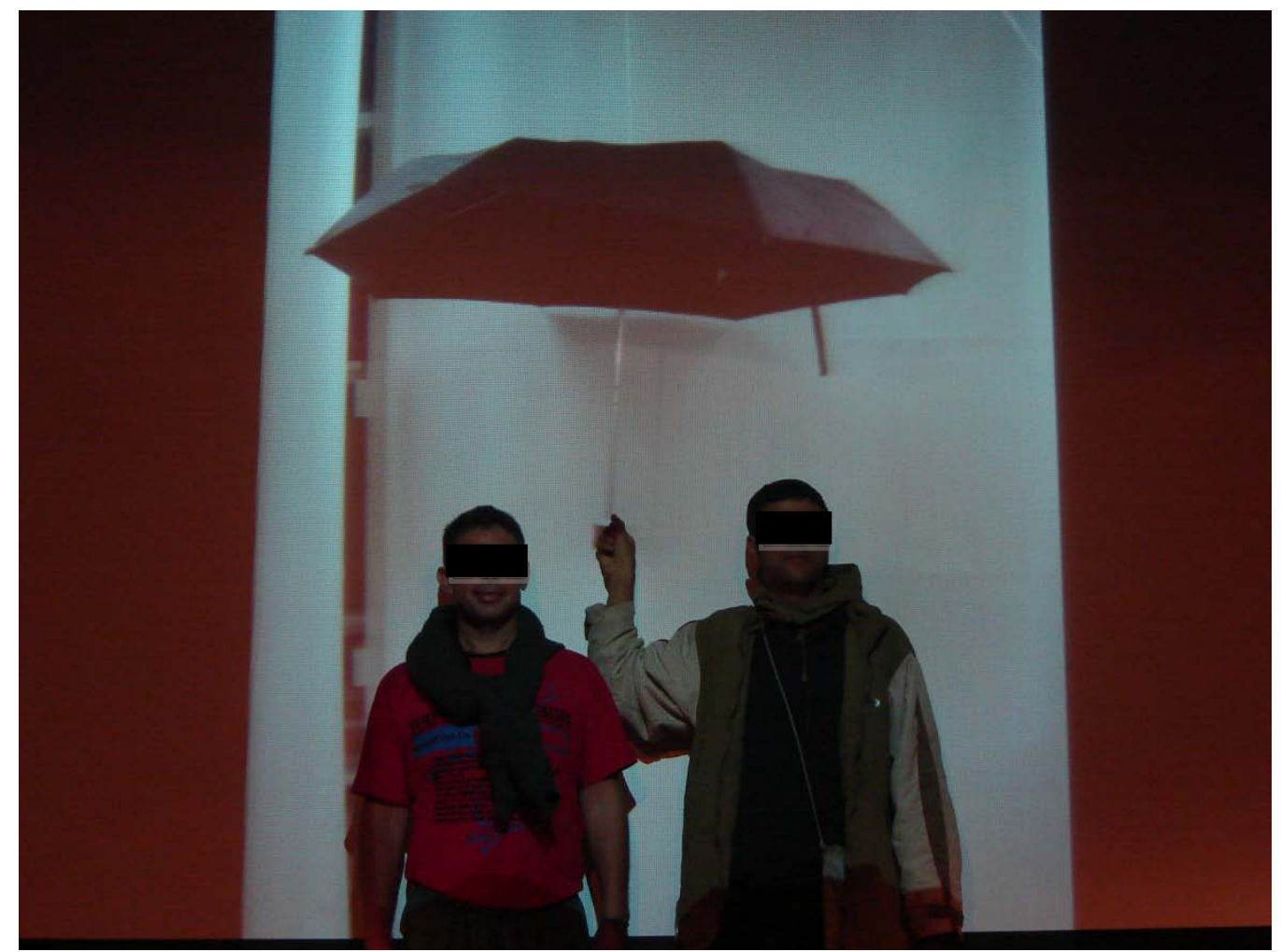

Figura 4 - Fotografia tirada em 12.11.2007. Intervenção na produção do dia 05.11.2007. 


\section{ANEXO 5}

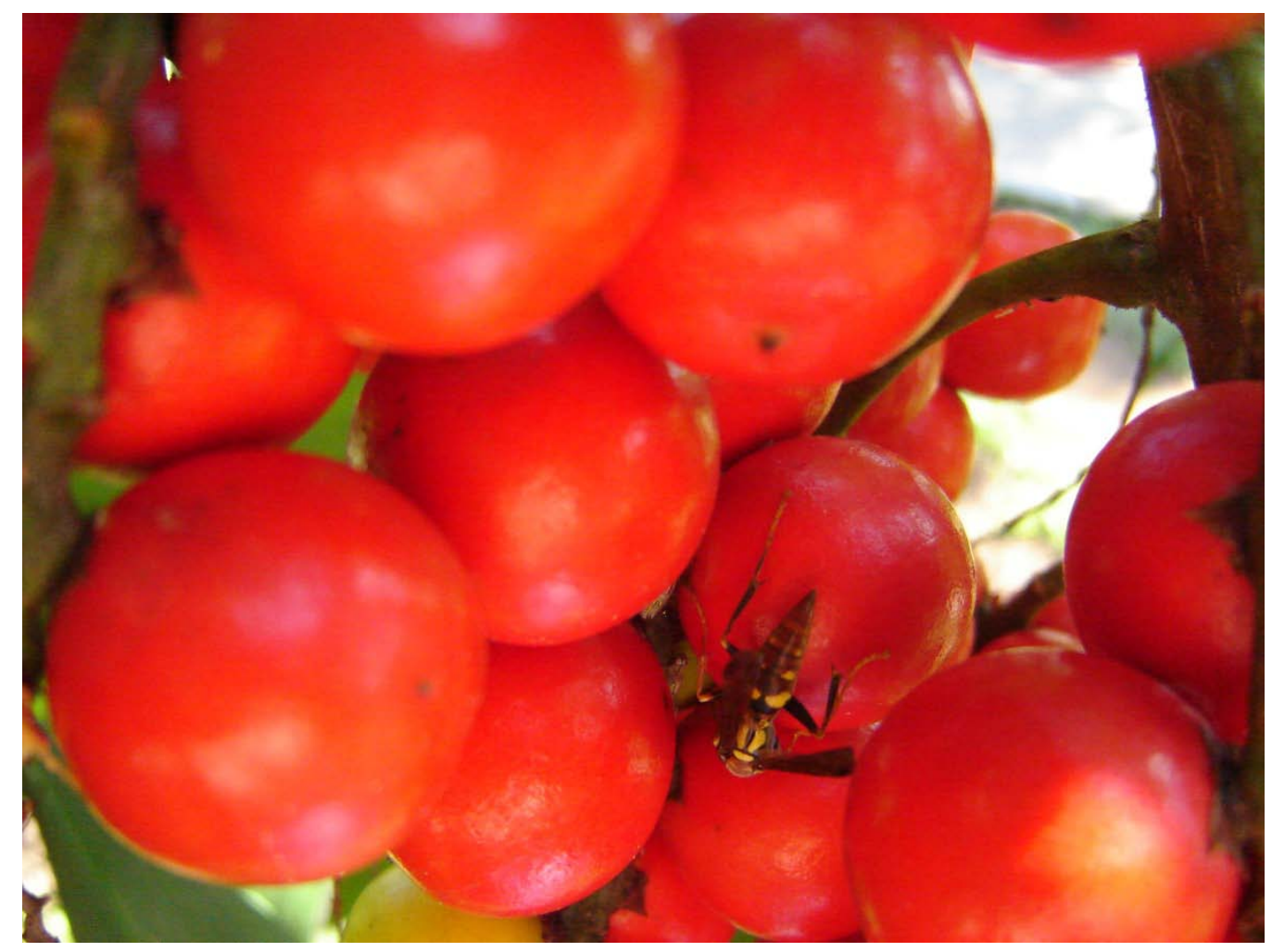

Figura 5 - Fotografia tirada em 26.03.2007. Aula sobre técnica de fotografar objetos próximos, apelidado de "A florzinha". 


\section{ANEXO 6}

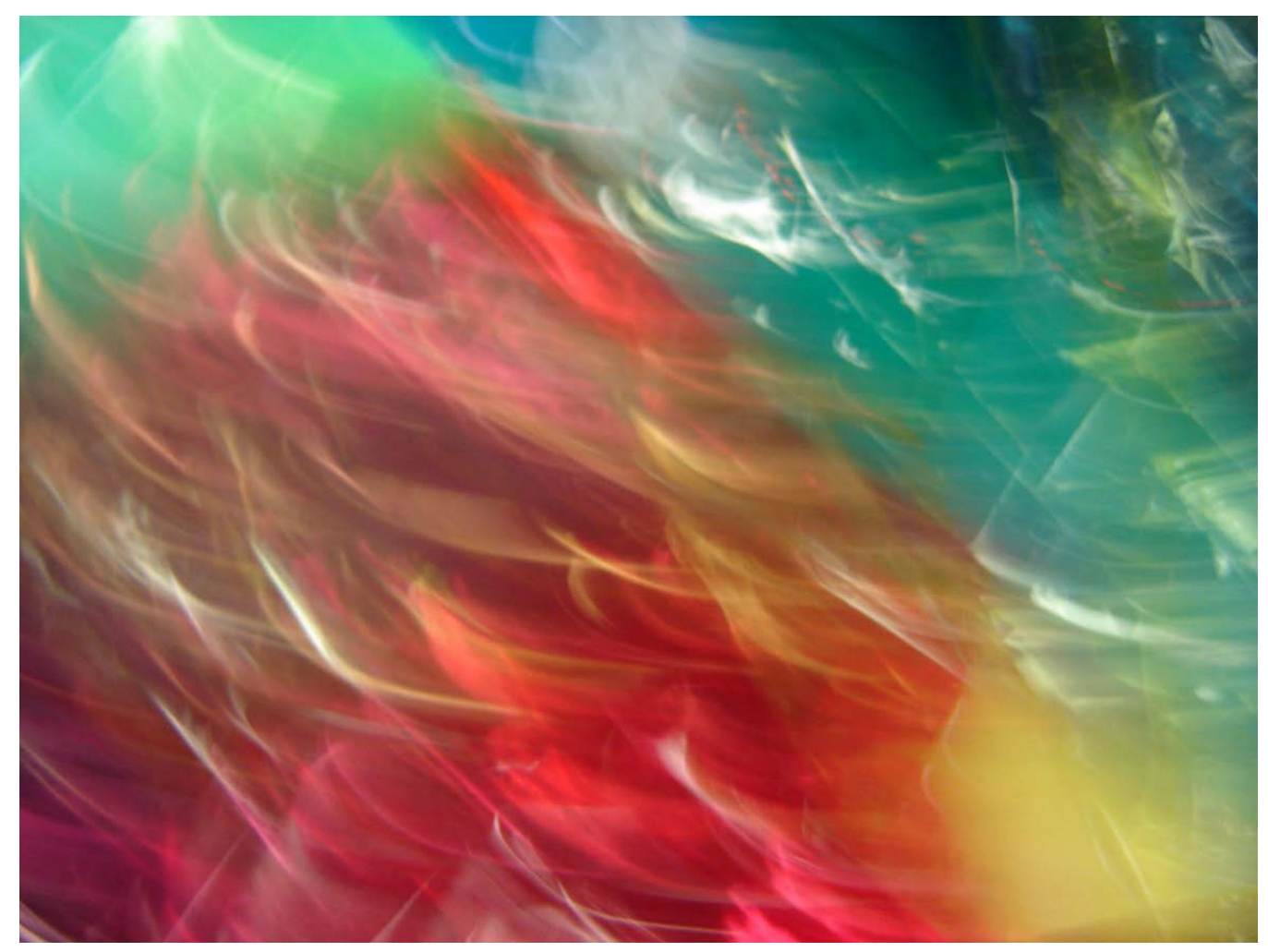

Figura 6 - Fotografia tirada em 23.06.2008. Aula utilizando luz, técnica abertura de diafragma e velocidade da câmera fotográfica. 


\section{ANEXO 7}

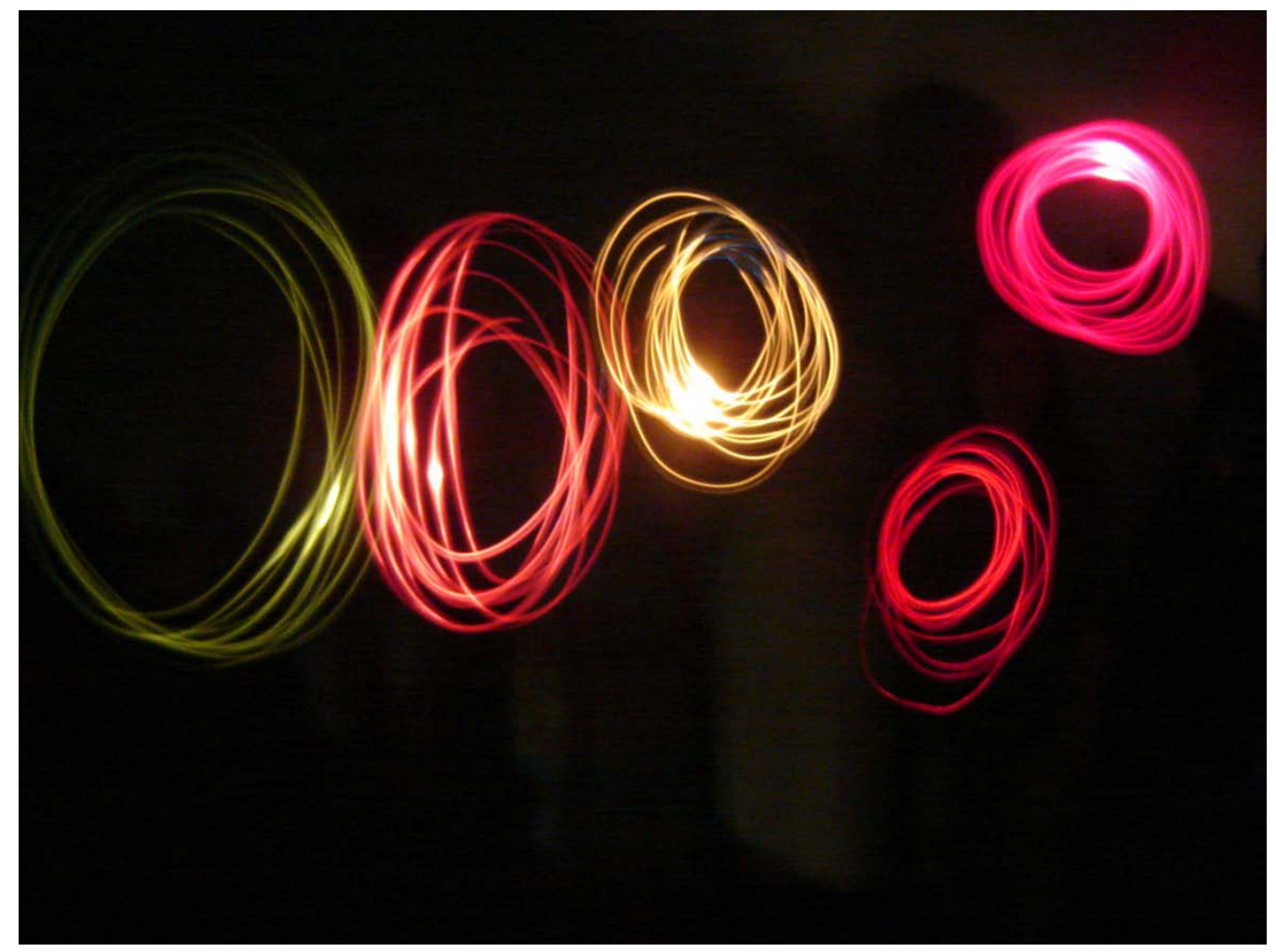

Figura 7 - Fotografia tirada em 07.05.2007. Aula sobre "Luz" e técnica de abertura de diafragma da câmera fotográfica. 


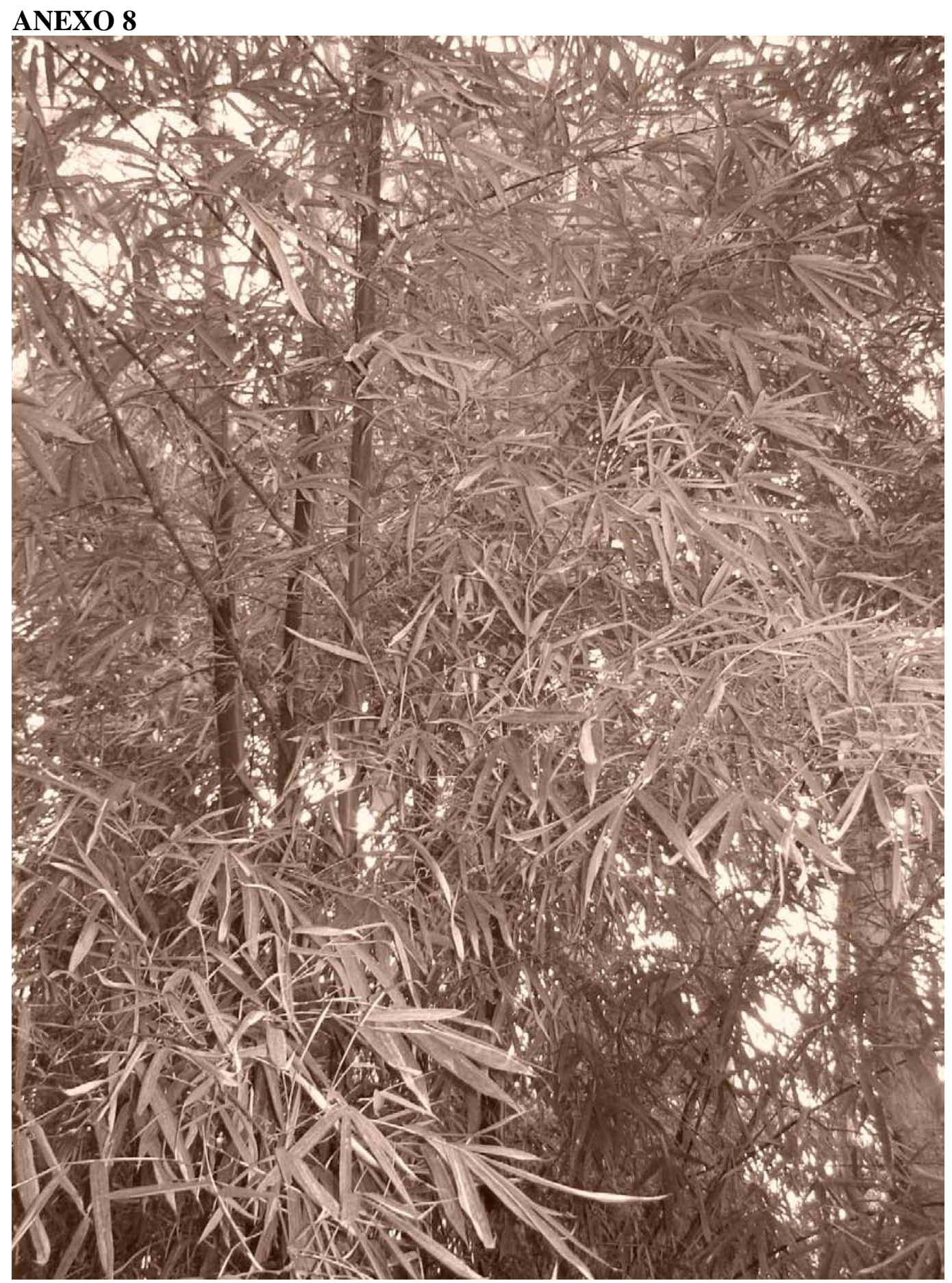

Figura 8 - Fotografia tirada em 25.06.2008. Sépia. 


\section{ANEXO 9}

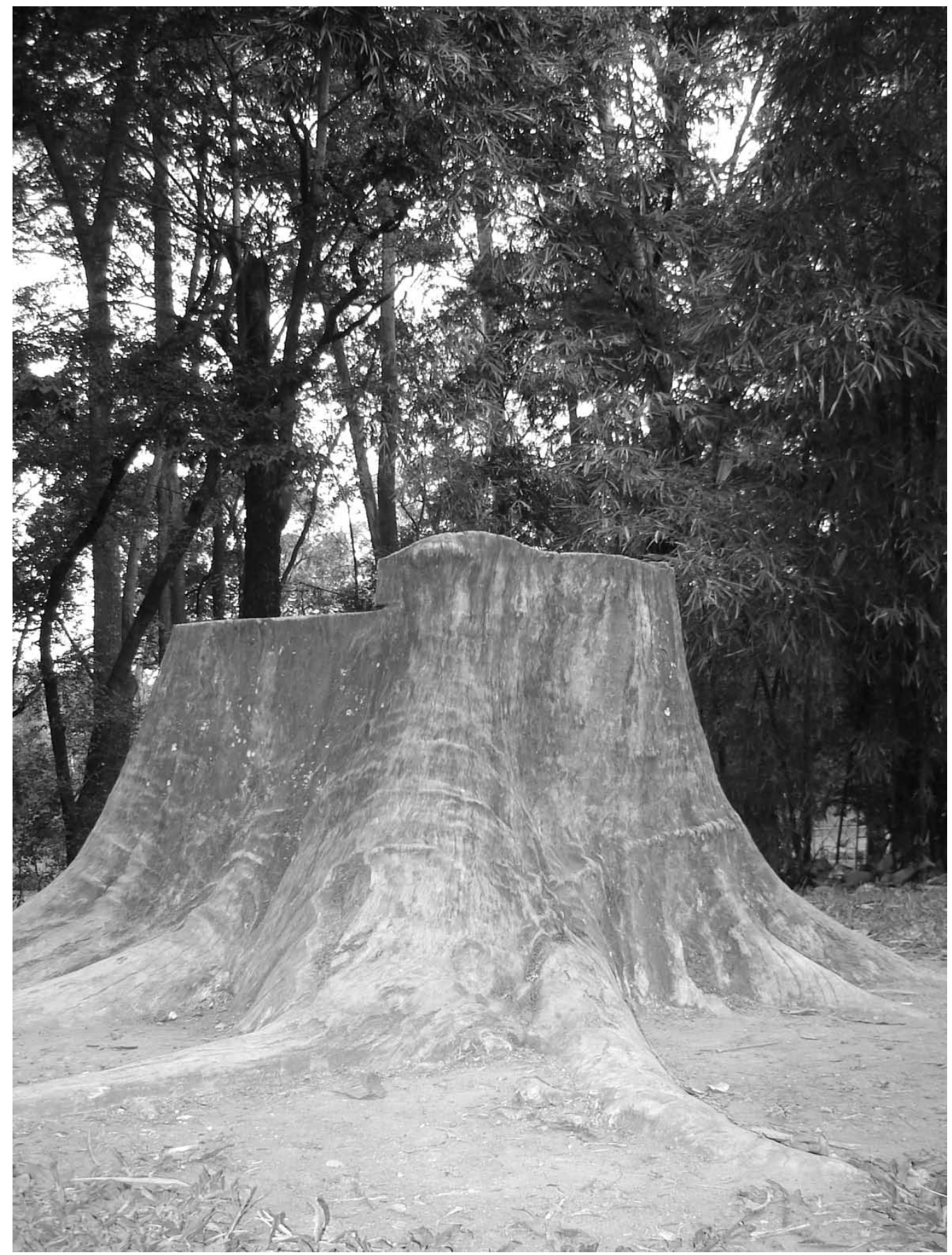

Figura 9 - Fotografia tirada em 25.06.2008. Preto e Branco. 
ANEXO 10

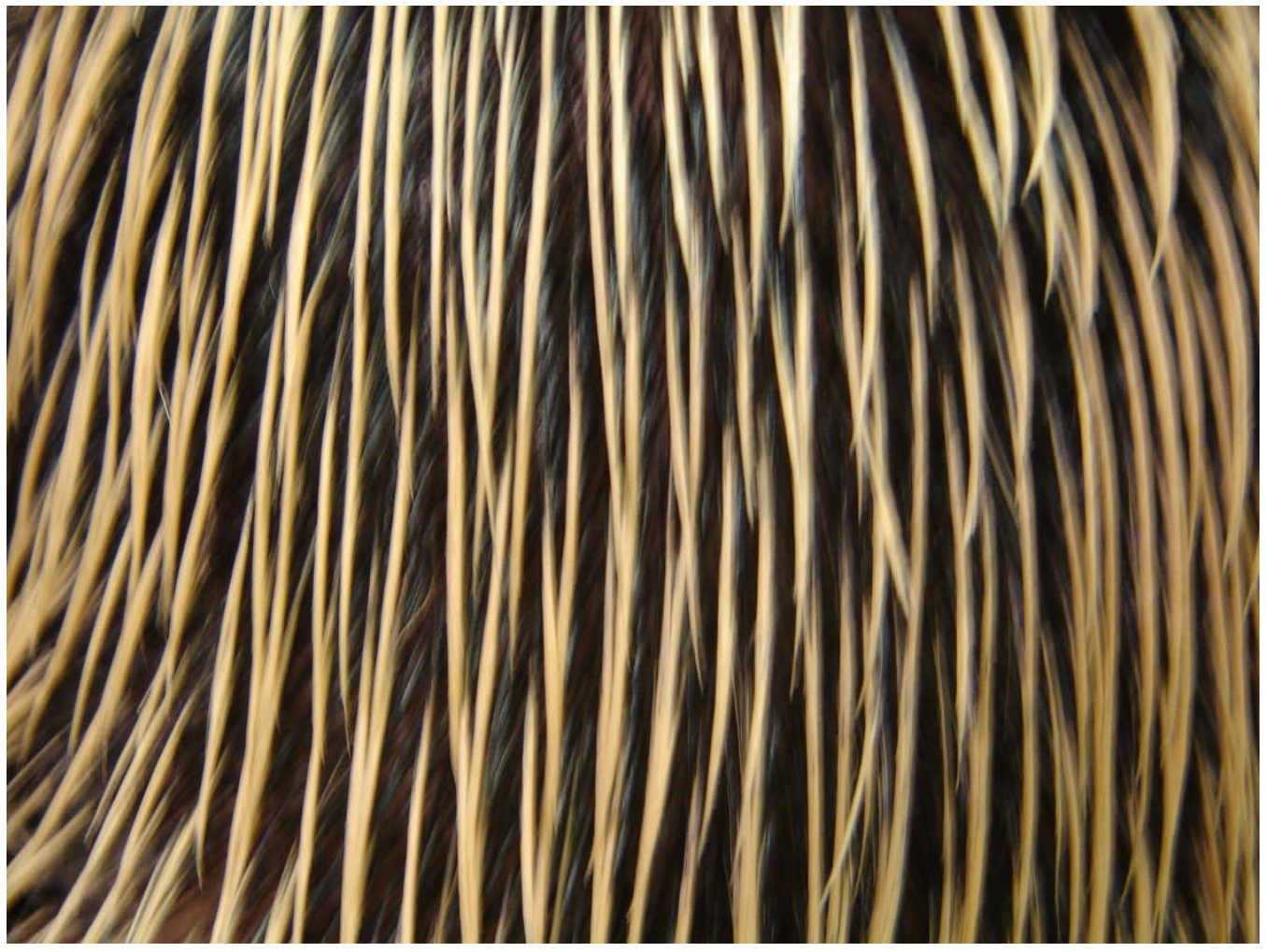

Figura 10 - Fotografia tirada em 05.11.2007. Aula cujo objetivo era fotografar algo que o representasse. Este é o cabelo do autor da fotografia. Sua "marca registrada". 


\section{ANEXO 11}

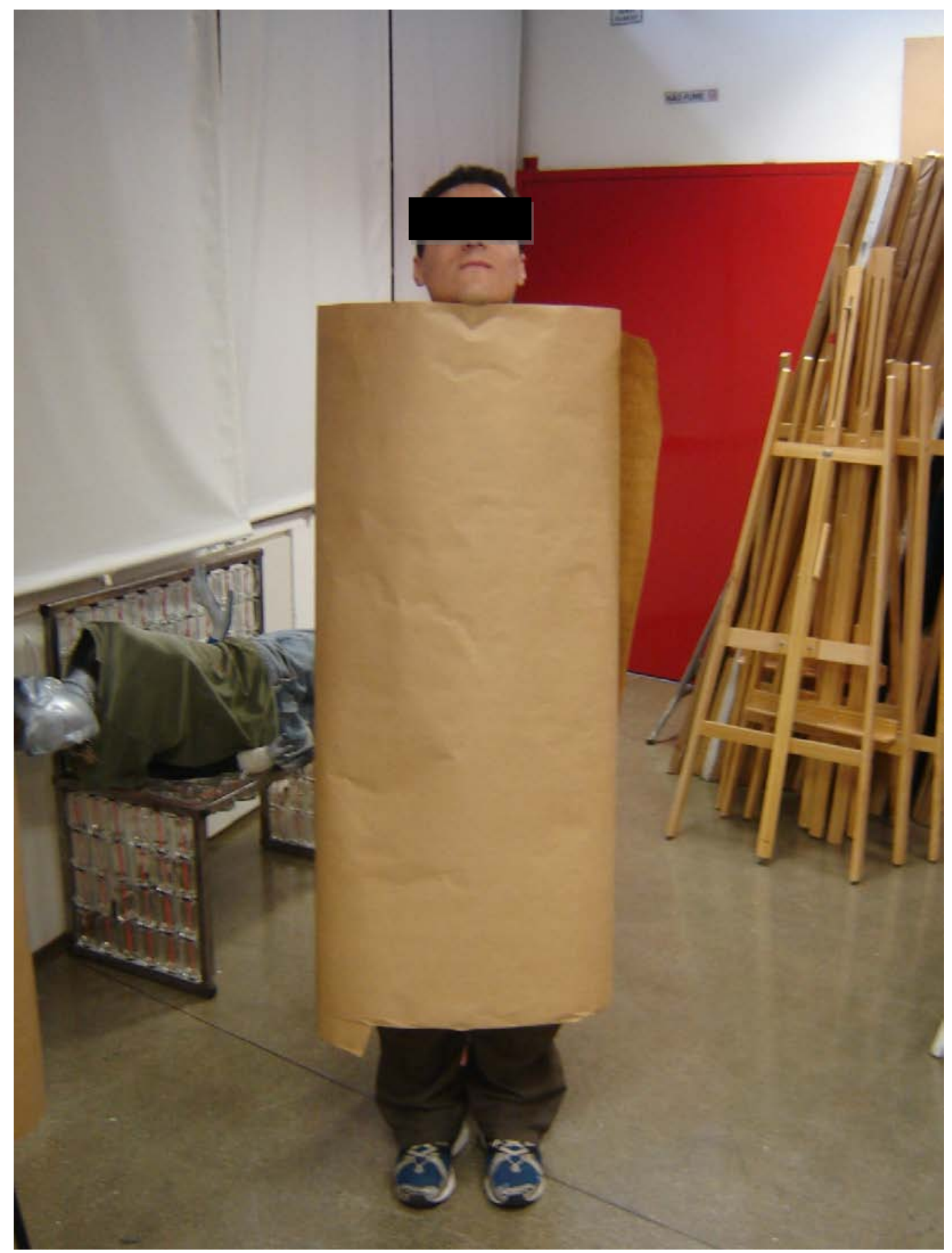

Figura 11 - Fotografia tirada em 01.09.2008. 


\section{ANEXO 12}

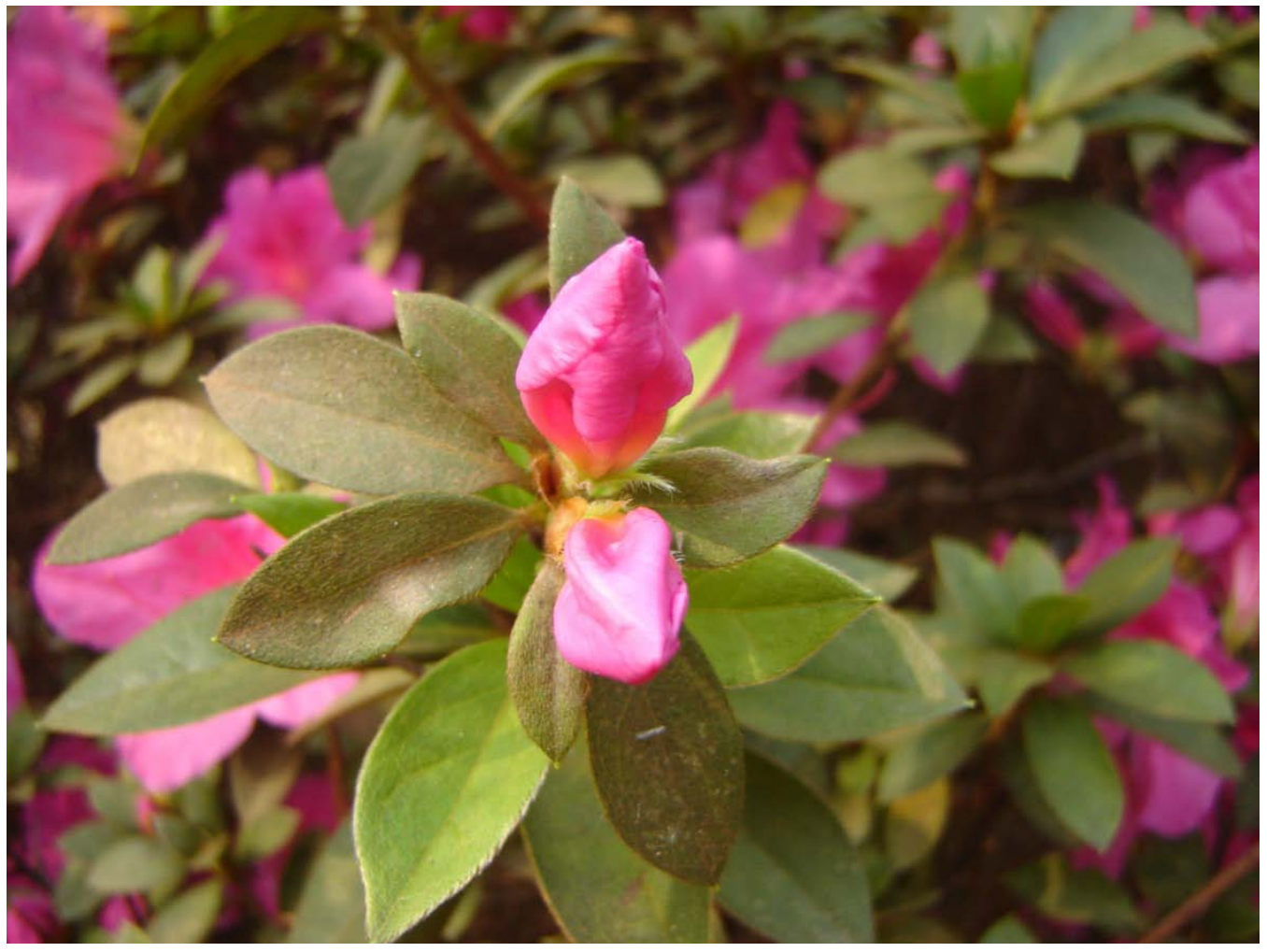

Figura 12 - Fotografia tirada em 27.08.2007. Aula de Fotosequência.

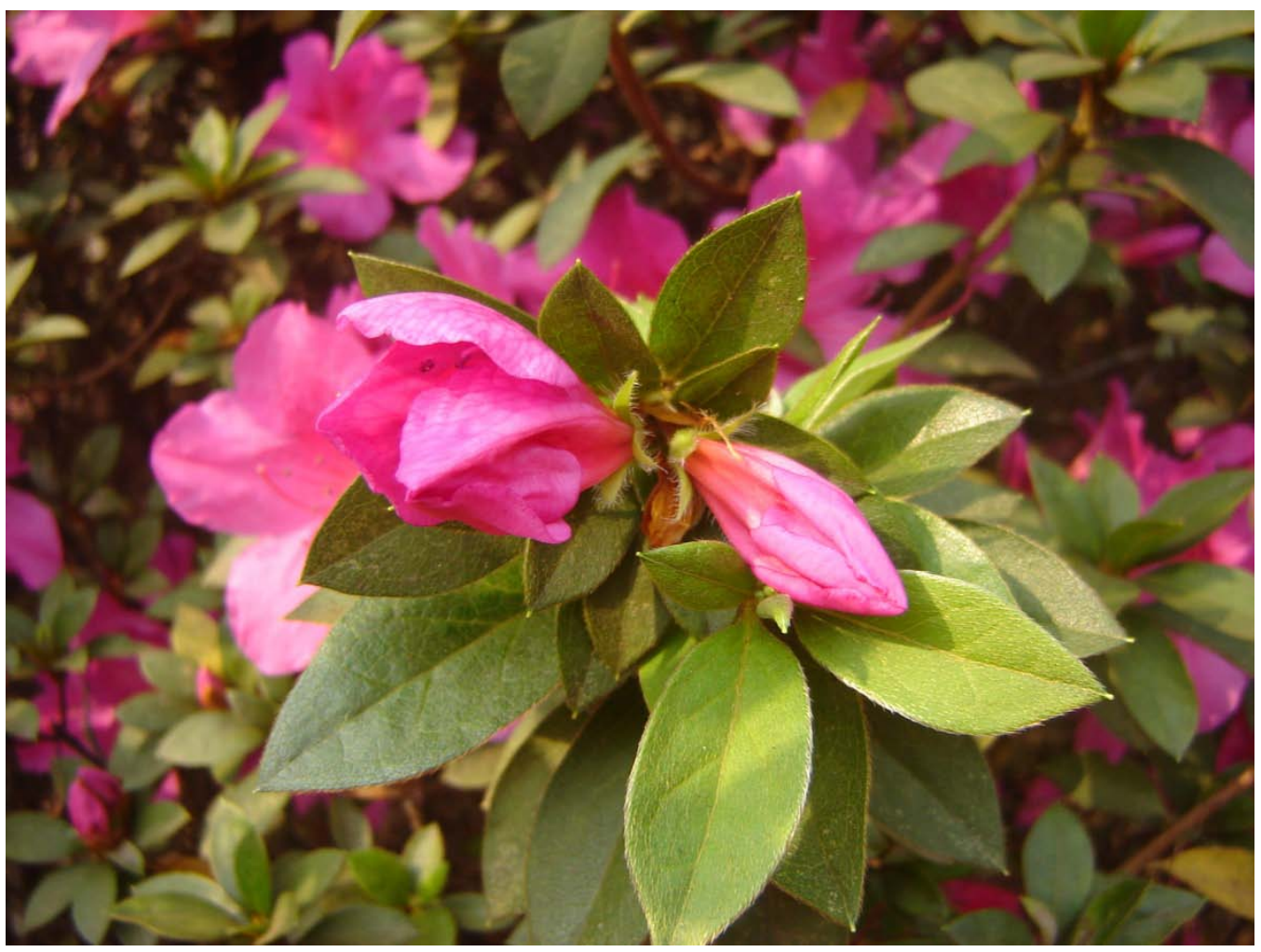

Figura 13 - Fotografia tirada em 27.08.2007. Aula de Fotosequência. 


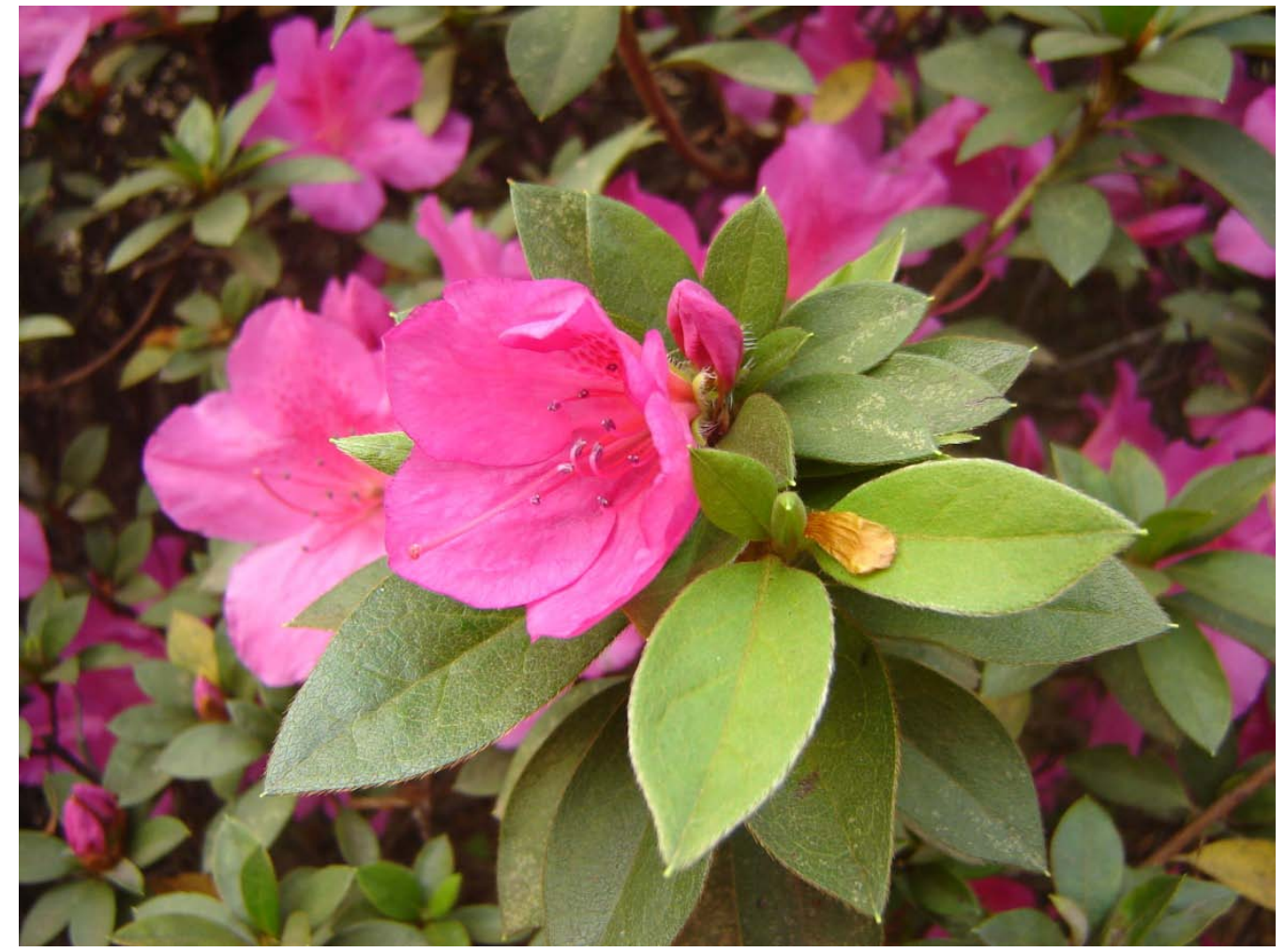

Figura 14 - Fotografia tirada em 27.08.2007. Aula de Fotosequência.

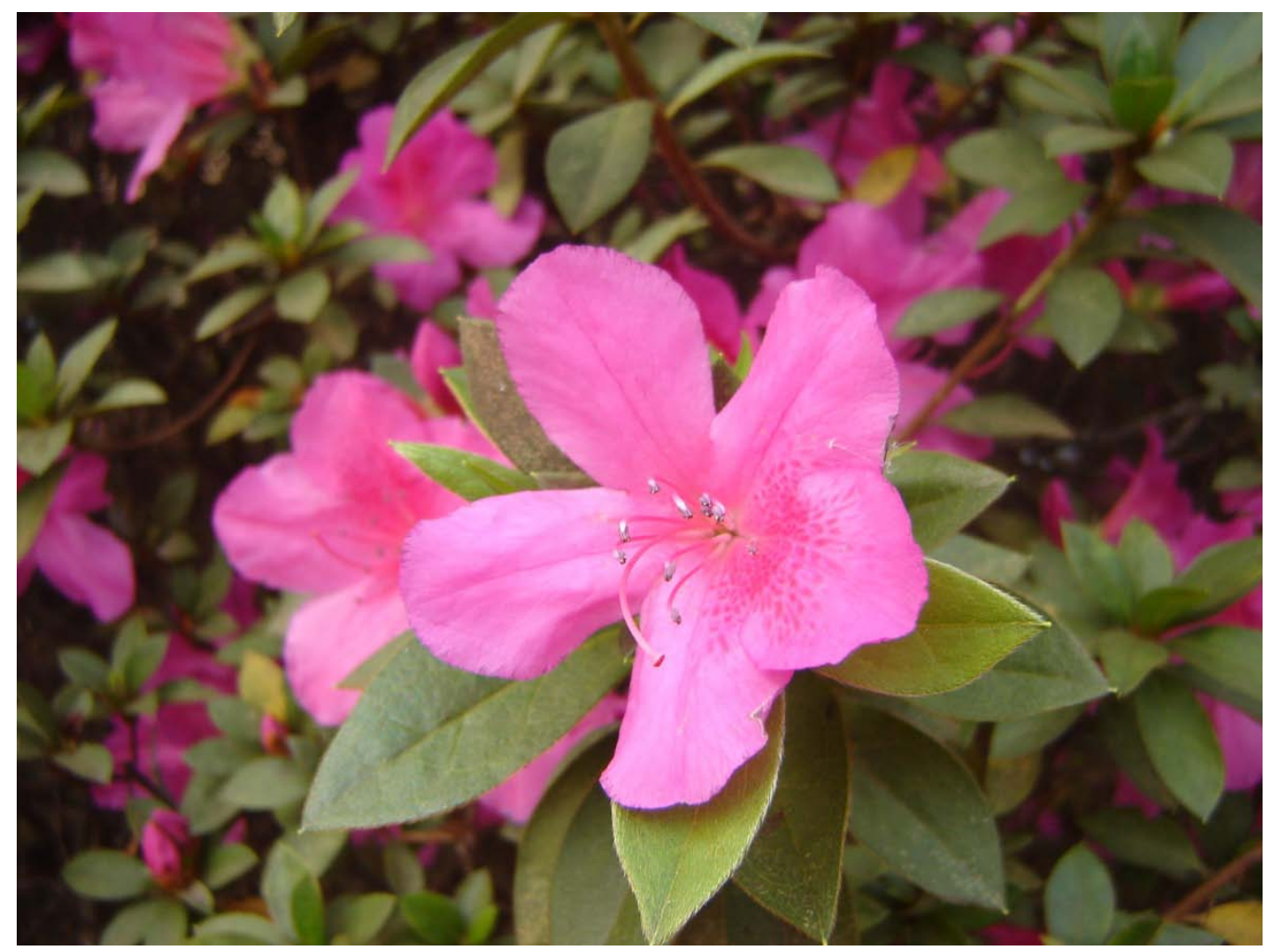

Figura 15 - Fotografia tirada em 27.08.2007. Aula de Fotosequência. 


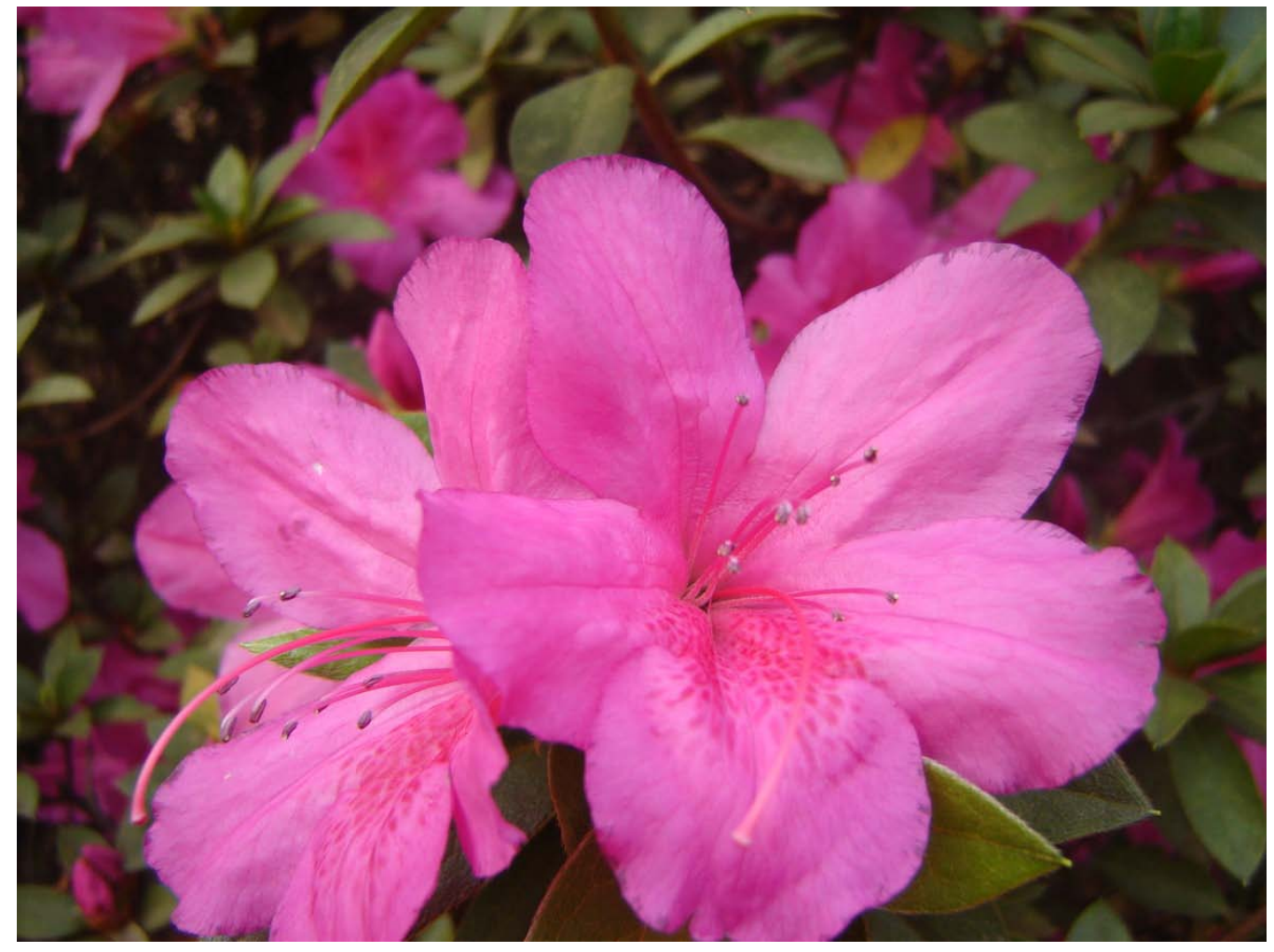

Figura 16 - Fotografia tirada em 27.08.2007. Aula de Fotosequência. 